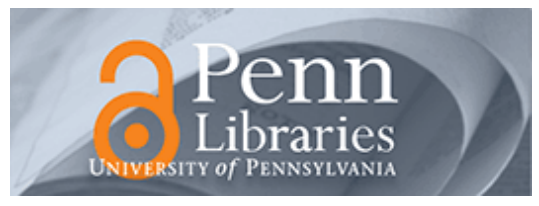

University of Pennsylvania ScholarlyCommons

\title{
8-2009
}

\section{Modes of Cooperative R\&D Commercialization by Start-Ups}

Vikas A. Aggarwal

University of Pennsylvania

David H. Hsu

University of Pennsylvania

Follow this and additional works at: https://repository.upenn.edu/mgmt_papers

Part of the Business Administration, Management, and Operations Commons, Business Intelligence Commons, E-Commerce Commons, and the Strategic Management Policy Commons

\section{Recommended Citation}

Aggarwal, V. A., \& Hsu, D. H. (2009). Modes of Cooperative R\&D Commercialization by Start-Ups. Strategic Management Journal Strategic Management Journal, 30 (8), 835-864. http://dx.doi.org/10.1002/smj.765

This paper is posted at ScholarlyCommons. https://repository.upenn.edu/mgmt_papers/28

For more information, please contact repository@pobox.upenn.edu. 


\title{
Modes of Cooperative R\&D Commercialization by Start-Ups
}

\begin{abstract}
This study empirically examines the determinants of heterogeneous firm-level cooperative R\&D commercialization strategies. While the volume of interfirm collaboration has increased dramatically in recent decades, the determinants of firm-level choices among alternate modes of such cooperative activity remain relatively understudied. We develop a conceptual model of factors determining collaborative mode choice at the organizational portfolio level. These factors include the firm-level appropriation environment, in which deal-level choices have portfolio-level spillover implications, as well as governance capabilities developed by the firm over time. Using a random sample of innovating biotechnology start-ups, we assemble a firm-year panel dataset that aggregates transaction-level collaboration data to the firm-year level, allowing us to characterize firms' portfolios of collaborative deals. We find broad empirical support for our model, suggesting that a firm's appropriation environment and governance capabilities strongly influence portfolio-level collaboration mode choices. In addition, we explore the implications of governance capability development, finding that experience with particular modes, as well as deviations from existing capabilities, impact firm valuation.
\end{abstract}

\section{Keywords}

strategic alliances, technology commercialization, entrepreneurship, biotechnology

Disciplines

Business Administration, Management, and Operations | Business Intelligence | E-Commerce | Strategic Management Policy 


\title{
Modes of Cooperative R\&D Commercialization by Start-ups
}

\author{
by \\ Vikas A. Aggarwal \\ The Wharton School \\ University of Pennsylvania \\ 2058 Steinberg-Dietrich Hall \\ Philadelphia, PA 19104 \\ Tel: 415-378-5844 \\ vikasa@wharton.upenn.edu \\ David H. Hsu \\ The Wharton School \\ University of Pennsylvania \\ 2028 Steinberg-Dietrich Hall \\ Philadelphia, PA 19104 \\ Tel: $215-746-0125$ \\ dhsu@wharton.upenn.edu
}

Draft Date: July 2006

\begin{abstract}
This paper empirically examines the determinants of heterogeneous cooperative R\&D commercialization strategies of innovating biotechnology start-ups. While the volume of inter-firm collaboration, spanning modes such as strategic alliances and technology licensing, has increased dramatically in recent decades, prior research has seldom analyzed the firm-level organizational choice between alternate modes of such cooperative activity. The organization of collaborative commercialization has important resource allocation, corporate development, and strategic implications for innovating firms, particularly in the biotechnology industry, as self-commercialization in this industry is rare. Using a random sample of over 100 biotechnology innovators, we assemble a firm-year panel dataset to examine the relative importance of organizational governance capability and transaction cost measures in explaining the variation in cooperative mode choice. We do this by aggregating transaction-level collaboration data to the firm-year level (thereby characterizing firms' portfolio of collaborative deals). In firm level analyses of collaborative choice intensities and transaction level analyses of alternate modes of organizing a deal, we find empirical support for organizational governance capability theories and mixed support for transaction cost theories. Moreover, we find that firm valuation is shaped both by experience in particular collaborative modes and by deviations from historic collaboration mode capabilities.
\end{abstract}

Keywords: Strategic alliances, corporate development, entrepreneurship, biotechnology.

\footnotetext{
${ }^{*}$ We thank Nick Argyres, Michael Leiblein, Dan Levinthal, Kyle Mayer, Harbir Singh, and conference participants at London Business School, the Atlanta Competitive Advantage Conference, and the Schumpeter Society for thoughtful comments. We thank Mark Edwards for granting us access to the Recombinant Capital database and Tong Zhao for excellent research assistance. We gratefully acknowledge the Mack Center for Technological Innovation at the Wharton School for funding this project.
} 


\section{Introduction}

Collaborative R\&D commercialization activity has increased significantly in recent decades (e.g., Hagedoorn, 2002), prompting a flurry of research seeking to explain the causes and consequences of this phenomenon. Increasing technological complexity and faster product cycle times are among the factors that have likely led to greater value chain specialization and made inter-firm collaboration a critical component of firm strategy in many technology-based industries (e.g., The Economist, 2005). For resource-constrained start-ups, collaborative commercialization strategies are particularly important, as the choice of forward-integrating into downstream production activities is sometimes not a feasible option. The organizational performance benefits of such cooperation have been documented in a wide range of settings (e.g., Shan, et al., 1994; Das, et al., 1998; Dyer, 2000; Rothaermel, 2001; GomesCasseres, et al., forthcoming).

Collaborative $\mathrm{R} \& \mathrm{D}$ commercialization strategies have also received attention because of the potential productive efficiency effects associated with the division of labor between upstream innovation by start-ups and downstream commercialization by more established firms with complementary assets (Gans, et al., 2002). This structure allows for specialization in the economy (and associated firm-level benefits such as lower cost structures). There are also societal gains in avoiding duplication of investments in overlapping commercialization activity, costs which would prevail in the absence of the possibility of inter-organizational commercialization. Both firm and social benefits are enabled through cooperative commercialization (though perhaps in differing degrees), regardless of the organizational form employed.

For this reason most of the prior literature has treated various types of collaborative activity as a single class of activities, abstracting away from different structures of such activities (e.g., by bundling together analyses of various forms of strategic alliances and technology licensing). Another potential reason for not explicitly considering the differences in collaborative organizational structures is that in economic equilibrium, alternate forms of collaboration may be predicted to be profit neutral. Under the condition that organizations and their managers have rational expectations about the profit and risk potentials of alternate cooperation structures, they are arguably financial substitutes for one another. However, in addition to real world deviations from such (perfectly) rational managerial behavior, while alternate cooperation modes may accomplish similar functions, some efforts can be more targeted and appropriate than others (Dyer et al., 2004). In addition, there are several organizational reasons why the mode of collaborative commercialization might matter.

From the perspective of the start-up innovator, selecting a given cooperative mode over another may have a host of resource allocation, corporate development, and strategic implications. Consider for example a firm such as Qualcomm, the wireless communications semiconductor company, which has 
chosen to specialize in technology licensing, electing to earn the majority of its returns from its innovation through arm's-length licensing of its technological developments. Such an organization will tend to allocate its resources to develop a significant capability in producing patentable inventions through its technical staff, perhaps at the expense of other organizational investments such as manufacturing or sales/marketing excellence. Particularly for resource-constrained start-up innovators, developing a distinctive capability in one area may be a strategic choice with the associated trade-off of not being at the leading edge of another organizational domain.

Start-ups' decisions to pursue one collaborative form over another also have implications for industry incumbents, as recipient firms of technology transfer will have to devote varying levels of managerial attention, oversight, and resources in governing different types of inter-organizational relationships. Consider for example Cisco Systems, the communications network equipment supplier, with a reputation for acquiring and integrating innovative start-ups. While acquisitions are an extreme form of innovator cooperation, the economic efficiencies discussed above are also associated with this action. Organizations which frequently acquire start-up innovators likely invest relatively more resources in acquiring evaluation and integration capabilities.

Given the organizational and strategic importance of alternative forms of structuring interorganizational cooperation, we ask the following two interlinked research questions: (1) what drives variation in the collaborative forms chosen by start-ups in commercializing their innovations? and (2) what are the corporate valuation implications of firm investments in capability development?

The transaction cost economics literature has informed the collaborative mode issue largely from a transaction-level governance perspective (e.g., Williamson, 1975; Pisano, 1989; Oxley, 1997), while recent research at comparing transaction and organizational resource based theories (e.g., Leiblein and Miller, 2003; Sampson, 2004a; Mayer and Salomon, 2006) address transaction-level governance as the outcome to be explained. In this paper, we jointly examine the impact of transaction cost and firm governance capability influences on firm-level collaboration choices from an organizational portfolio perspective. While understanding governance choice at the transaction level is undoubtedly important, managers likely also conduct both make and buy transactions in their firms across their portfolio of projects. As a result, organizational governance mode choices likely take into account both transaction level hazards as well as firm governance capability considerations. We also analyze the choice of alternate collaborative governance modes at the transaction level to compare and triangulate our firmlevel results. In doing so, our approach is consistent with an emerging literature stream which suggests 
that a firm-level analysis utilizing multiple theoretical lenses can yield important insight into $R \& D$ governance choice (e.g., Villalonga and McGahan, 2005 ${ }^{1}$ ).

For start-up firms, understanding the drivers of heterogeneous collaborative modes of commercialization is extremely important, as resource constraints may limit their ability to selfcommercialize their innovations. We therefore choose an empirical setting in which we can abstract away from the self-commercialization option and focus solely on the choices among various modes of commercialization: biotechnology is an industry in which some form of cooperation is an overwhelmingly common commercialization strategy ${ }^{2}$, and our approach is to randomly select a set of over 100 biotechnology innovators to examine the relative empirical importance of both organizational governance capability and transaction cost theory explanations in explaining firms' collaborative mode choice intensities. We find strong support for governance capability theories and mixed support for transaction cost theories. Moreover, we find firm valuation consequences associated with both collaborative mode governance experience and deviations from historic cooperation mode governance capabilities. In the next section, we discuss the literature and hypotheses underlying our analysis. We then turn to a discussion of the research design, followed by a description and discussion of our empirical results. A final section concludes.

\section{Literature and Hypotheses}

This section begins with an introduction to themes and approaches in the literature on organizing and governing modes of collaborative commercialization. We then motivate the rationale underlying our choice of examining equity-use and arm's-length licensing as focal modes of cooperation. The next section discusses predicted drivers of firm level cooperative mode behavior, while a final section explores the valuation implications associated with collaborative mode use and development.

\section{A. Background}

In analyzing the issue of collaborative mode choice and governance, many early studies drew from the transaction cost economics (TCE) paradigm. The theory lends itself naturally to understanding heterogeneous transaction-level governance choices by considering contractual hazards, expropriation

\footnotetext{
${ }^{1}$ Our study is perhaps closest in spirit to this study, in which the authors conduct a comprehensive assessment of firm boundary scope decisions (and their drivers) varying from divestitures to alliances to acquisitions. While we do not examine the range of firm boundary choices they do, we analyze the variation among different alliance forms (which Villalonga and McGahan [2005] do not treat) due to the organizational and strategic rationale previously discussed. As they do, we conditional our analysis on firms' decision to undertake a change in their organizational boundaries, thereby studying the variation among the various organizational collaboration modes.

${ }^{2}$ For example, Gans, et al. (2002) find that biotechnology has the highest probability of cooperation when compared to other technology-intensive industrial segments in their sample, including industrial equipment, instruments, software and electronic equipment.
} 
risks, and asset specificities (Williamson, 1975). Transaction cost theories have been used to examine a wide range of organizational design issues ranging from vertical integration (Monteverde and Teece, 1982), equity use in collaborative $R \& D$ relationships (Pisano, 1989), as well as alliance governance issues (Oxley, 1997).

Another influential stream of research on alliance governance has emphasized the role of interorganizational trust and reputation at the firm and network levels of analysis (e.g., Gulati, 1998 and references therein). The critique of TCE-based studies from this group of researchers is that focusing on contractual hazards at the transaction level of analysis is under-socialized (since transactions are situated in bilateral or multilateral terms, and so transactions should not be regarded as discrete and independent events). Consequently, these scholars conclude that studies at higher levels of analysis are necessary. Poppo and Zenger (2002) addressed the debate pitting formal contracting versus relational governance, finding that the two approaches can be reinforcing complements rather than dividing substitutes. ${ }^{3}$

A third stream of literature stems from the resource-based (Wernerfelt, 1984) and relational (Dyer and Singh, 1998) views, which serve as the theoretical core of studies related to organizational capability development among alliance partners (e.g., Kale, et al., 2002; Zollo, et al., 2002). These studies have examined the influence of capabilities and routines at the firm and inter-organizational levels on the formation, governance and success of collaborative relationships.

With this backdrop, the recent literature on alliance governance has examined the relative importance of TCE and organizational capability theories in explaining cooperative governance structure (while sometimes also investigating relational contracting views). These studies have been marked by a move to examining multiple theories simultaneously (e.g., Colombo, 2003; Leiblein and Miller, 2003; Sampson, 2004a; Villalonga and McGahan, 2005; Mayer and Salomon, 2006). At the same time, however, the legacy of TCE is strongly present in these and most studies in this literature (the Villalonga and McGahan [2005] article is the exception), in that the outcome to be explained across these studies is the organization of a given transaction (e.g., make versus buy and/or equity-use versus not) with an accompanying extent of vertical integration/hierarchy interpretation.

While understanding governance choice at the transaction level is undoubtedly important, managers likely also conduct both make and buy transactions in their firms across their portfolio of projects. As a result, organizational governance mode choices likely take into account both transaction level hazards as well as firm governance capability considerations. ${ }^{4}$ Taking this perspective may help, for

\footnotetext{
${ }^{3}$ Similarly, Eisenhardt and Schoonhoven (1996) found that strategic and social explanations were both important in explaining alliance formation.

${ }^{4}$ While the TCE tradition tends to emphasize costs of organizing a transaction outside organizational boundaries, the firm capability paradigm tends to stress the benefits associated with collaboration. A fertile area of future research may be to develop a more balanced view across these theories.
} 
example, in explaining the phenomenon of firms facing similar levels of contracting hazards choosing different ways of organizing their transactions (Argyres and Liebeskind, 1999; Mayer and Salomon, 2006). ${ }^{5}$

For start-up firms, particularly in industrial sectors marked by specialized and/or expensive complementary assets (Teece, 1986), understanding the drivers of heterogeneous collaborative modes of commercialization is extremely important, as resource constraints may limit their ability to selfcommercialize their innovations. Such modes can span arm's length technology licensing on one end of the spectrum to tight, equity-based collaboration on the other, with various shades of grey in between (more on this below).

We therefore abstract away from the self-commercialization option, focusing on variation among cooperative forms. We also depart from the existing stream of studies comparing transaction cost and resource-based explanations by examining the firm-level organizational choices of cooperative mode. Much of the prior literature in this stream has focused on individual governance decisions for particular transactions as the outcome to be explained. While we include a transaction-level analysis in our empirical results, a main contribution of this paper is the conceptualization of our outcome variables as organization-level strategic choices. We argue that resource allocation decisions such as the creation of a dedicated alliance function (Kale, et al., 2002) or the allocation of particular personnel to corporate development roles are strategic decisions made at the firm level which take into account factors such as the expected level of future contractual hazards and existing organizational governance capabilities. Thus, while aggregate firm-level factors impact the choice of governance for individual transactions, they can also impact the ways in which managers conceptualize portfolios of governance decisions.

\section{B. Modes of organizing collaboration}

While there are clearly a wide variety of forms in which collaborative commercialization can be organized, spanning the dimensions of contractual formality, level of inter-organizational integration, and equity use (e.g., Kale and Puranam, 2004), we focus on firms' use of two collaborative contractual features. The first, equity-use, is an indicator of organizational hierarchy (among other things), ${ }^{6}$ while the second, arm's length licensing, allows for division of labor between innovators and commercializers (Arora et al., 2001; Gans et al., 2002). Organizational specialization in governing via one mode more intensively versus the other has implications for investments and resource allocation within the firm (e.g.,

\footnotetext{
${ }^{5}$ It is interesting to note that while the first of these two studies emphasizes transaction-specific issues, particularly on contracting, the second study moves more to a broader firm capability interpretation, though again, with the aim of explaining variation in transaction-level governance form.

${ }^{6}$ As Gulati and Singh (1998) argue, alliance coordination costs, which do not necessarily coincide with equity use, is also an important factor in alliance governance design. Due to measurement issues in our empirical context, we abstract away from this distinction.
} 
recruiting certain types of technical and legal personnel) and for organizational design more broadly (e.g., setting personnel incentive schemes). Therefore, we elaborate on each of these modes in this section.

\section{Equity use}

While Gulati (1995) suggests that non-equity alliances are the default mode for organizing alliances, the literature has highlighted a number of situations in which equity use may be beneficial. Equity is generally tied to greater formal control in inter-organizational governance, which may be particularly important in mitigating the threat of transactional hazards (e.g., Pisano, 1989; Oxley, 1997). In the context of strategic alliances, equity use has also been conceptualized as helpful in capturing upside gain through option value (Santoro and McGill, 2005), enhanced monitoring and information acquisition (Filson and Morales, 2006), and in enabling learning effects (Anand and Khanna, 2000).

More generally, Kale and Puranam (2004) discuss using equity from the perspective of technology in-sourcing, noting that equity use has benefits (preferential access to strategic resources, alignment of interests between partners, and the ability to solve coordination and control issues) as well as costs (lowered motivation among employees and the loss in option value associated with commitment), suggesting that managers should carefully consider these tradeoffs when structuring technology sourcing deals. Overall, the various studies suggest that the use of equity in alliances can help mitigate uncertainty, reduce hazards of expropriation, and better enable learning to occur between organizations. We thus focus on equity as an important distinguishing feature of collaborative relationships.

In considering non-equity methods of organizing collaborative relationships, there are surely a myriad of such alternative alliance forms, including supply arrangements and other non R\&D activities. We are, however, particularly interested in those forms of collaboration in which a focal firm is seeking to commercialize an innovation. Therefore, those contractual arrangements which lead to the transfer of technology or that enable the creation of markets for intellectual property are of particular interest. The literature has discussed the use of arm's-length licensing relationships in this vein. Licensing allows firms to utilize markets for technological assets while avoiding the use of more integrative and hierarchical contractual forms. Consequently, we now turn our attention to arm's length technology licensing.

\section{Arm's-length licensing}

The prior literature has discussed the impact of licensing activity on markets for technology and on the associated innovation incentives for firms. Markets for technology allow division of labor between upstream R\&D and downstream commercialization activity, facilitating specialization in the economy and associated benefits such as lower cost structures at the firm and societal levels. Other societal gains include avoiding duplication of investments in overlapping commercialization activity. These effects are 
enabled through cooperative commercialization more generally, regardless of mode; however, the effects are most undiluted in the case of arm's-length licensing.

Arora, et al. (2001) suggest that markets for technology, which are facilitated by the presence of licensing contracts, can have important implications for industry competition, writing (p. 224) that such markets "lower the barriers of entry into the industry, increase competition, and compress product life cycles." These industry changes further affect corporate strategies, particularly for start-up firms. Arora et al. (2001) go on to state (p. 251) that start-ups need not necessarily invest in downstream assets, as they can "profit from their research even if they lack the complementary assets, or if the markets for such assets are underdeveloped" - which has the effect of enlarging the commercialization strategy space in this domain.

Many studies treat licensing as a distinct alliance form. Oxley (1997) uses a hierarchy of alliance types, in which bilateral contracting represents a licensing relationship, while Anand and Khanna (2000) explore the degree to which learning effects exist for licensees. While licensing relationships sometimes come bundled together with a variety of other features such as co-development or co-marketing, we utilize a relatively narrow definition of licensing activity in this study, focusing only on licensing activity in which there are no other components to the relationship. We do this in order to capture pure technology arm's length licensing effects.

\section{Drivers of collaborative mode choice}

We now turn our attention to two primary explanatory categories for choice of collaborative form: transaction-specific factors and firm governance capability explanations. ${ }^{7}$ In both cases, we emphasize a firm-level perspective in order to understand how aggregate levels of transaction hazards and firm governance capabilities create variation in the mix of governance choices at the firm portfolio level.

\section{Transaction-related factors}

In the face of potential contracting threats associated with inter-organizational collaboration, innovators may consider at least three channels. The first channel is using a patenting and associated legal strategy to guard against expropriation threats. While patents constitute a right to exclude others from making, selling, or using an invention, such rights have to be enforced, which itself may be costly, particularly for some resource-constrained start-ups. Nonetheless, some innovators may wish to develop a reputation for asserting and enforcing their patent rights, which they hope will signal would-be infringers

\footnotetext{
${ }^{7}$ We concentrate on these explanations because they constitute central themes in the strategy and entrepreneurship literatures. Yet, we also recognize that we are not able to empirically study other considerations discussed in the literature, for example the proposition that alliance form depends on managerial intent, leading to a co-evolutionary process (Koza and Lewin, 1998).
} 
of potential consequences. The decision of whether to build such an organization level reputation impacts firms' choices in governing individual transactions.

A second channel firms can take to lessen expropriation threats is through the threat of withholding future deals from contracting parties. ${ }^{8}$ Of course the key to this innovator strategy is the repeated interaction element, and so this channel may be particularly important in at least two cases. If there is not a competitive supply of (future) complementary innovations accessible through other internal or external means to the party in-sourcing technology (thus enhancing the bargaining position of the innovating start-up), the "shadow of the future" effect will be especially important. A similar effect will hold if the innovating firm holds assets outside of the focal object of transfer which will add future value to the recipient, such as tacit knowledge held by the transferring party's knowledge workers or nontechnical specialized complementary assets. This second area, in particular, emphasizes organizationlevel effects which may importantly influence (and indeed transcend) transaction-level effects. Similarly, the configuration and structure of the social network in which the parties are embedded will impact the efficacy of withholding future deals from contracting parties. If the network is "closed" in the sense of parties having ties, directly or indirectly, with all other parties in the network, information about the behavior of entities within the network (which impacts firms' reputation) will spread more surely and quickly (Coleman, 1988). ${ }^{9}$

A third and final mechanism to assuage expropriation threats is through equity participation. While equity use is a commonly prescribed feature in organizing transactions marked by high opportunism threats, such a governance choice requires analyzing the contracting hazard associated with the focal transaction as well as expected levels of such hazards in future transactions faced by the organization as a whole. If a firm expects to use this feature sparingly in future transactions, it is unlikely that the organization will make the investment of learning how to structure and govern such transactions, as the learning curve may be too steep. Under this condition, firms may be willing to tolerate governance inefficiency in favor of using alternate governance channels. On the other hand, if the firm expects repeated equity use, managers may be more willing to experiment and learn about the most efficient way of structuring such transactions. Such efforts may entail specific organizational investments in an effort to institutionalize associated knowledge and learning, for example by establishing an equity specialist within an alliance development division and/or knowledge repositories (e.g., handbooks and manuals) to codify

\footnotetext{
${ }^{8}$ While we emphasize future transactions in this discussion, this mechanisms is consistent with the concept of deal scope as a source of appropriation in alliances (Oxley and Sampson, 2004; Sampson, 2004b), which we will rely upon in the empirical work.

${ }_{9}$ A related, albeit less formal, mechanism of appropriation is through inter-organizational trust (Gulati, 1995; Gulati and Singh, 1998), which can mitigate potential hazards.
} 
practices and procedures resulting from successful and less successful experiences in structuring prior equity alliances.

As previously mentioned, the decision to make such organizational investments depends on making multiple use of learning and knowledge associated with organizing equity transactions (via investment amortization and/or lower marginal cost in structuring the next transaction in a given manner). This decision in turn depends on the firm's current and expected technology and market areas (and the levels of uncertainty of each), as these factors shape the preferred governance channels available to the organization. Moreover, prior investments in learning to structure governance modes can influence firms' ongoing technological and strategic direction, as managers may choose future projects which are more likely to be aligned with equity use for those firms with experience in that domain. We will return to this theme in the next section.

The discussion in this section points to the conclusion that from an organizational perspective, individual transactions cannot be considered in isolation. Aggregate firm-level contractual hazards, together with an evaluation of the various organizational channels available to mitigate those hazards, are an important determinant of the firm's mix of governance forms. This results because firms must take into account the degree to which the focal transaction may impact the firm's choice of organization in future transactions. We therefore propose the following hypothesis:

- H1: When firms face contractual hazards, their collaborative mode choice at the organizational portfolio level will involve higher levels of equity use if alternate channels are not used to mitigate those threats.

\section{Firm governance capabilities}

While the literature has begun to allude to the possibility that firms' ability to govern their collaborative alliances might be a strategic organizational capability, we aim to develop a more complete picture in this paper. Villalonga and McGahan (2005) introduce the term "governance specialization" which they write (p. 1189) "measures the degree to which a firm has repeatedly engaged in deals of the current type." However, they do no elaborate on the concept except to show empirical evidence of its importance in explaining firms' choice among acquisitions, alliances and divestitures when altering their organizational boundaries. Mayer and Salomon (2006) argue that a firm's technological competence may indirectly enhance its governance capabilities (through enhancing parties' observability of technological milestones), which can in turn mitigate contractual hazards. In order to better understand the strategic fundamentals of governance capability, we address two questions in this section: What is an organizational governance capability, and how can such capabilities persist in use over time? 
The general requirements for a strategic capability have been well-explored in the literature, with the resource-based view conceptualizing a firm's competitive advantage as accruing from its unique set of valuable, rare and inimitable resources and capabilities (e.g., Wernerfelt, 1984). As a result, for governance structuring to be a firm capability, it must be difficult to replicate and not be an asset accessible on the open marketplace. ${ }^{10}$

In our conceptualization of governance capability, we focus on firms' prior governance structuring experience (building on Villalonga and McGahan [2005]). ${ }^{11} \mathrm{We}$ propose that governance capabilities represent an important firm resource and competence that significantly affects firms' choice of cooperative mode, as selecting alternate forms entail bearing greater risk (due to the lower level of knowledge associated with such forms). Early governance choices have a lasting impact shaping subsequent choices, leading to governance inseparability of current period organization from historic choices, sometimes compromising efficiency (Argyres and Liebeskind, 1999). Furthermore, governance capabilities result from organizational learning mechanisms and through firm investments in organizational structures aimed at developing competence in particular collaborative modes. In the remainder of this section, we address the question of how governance capabilities persist in use over time by first discussing the evolution of organizational governance capabilities and then turning our attention to governance inseparability-based explanations.

The concept of path dependence suggests that a firm's set of prior experiences plays an important role in conditioning both the menu of choices available in the present, and even (in some accounts) what firms select from the current menu of possibilities. While governance inseparability emphasizes a contractual foundation for this outcome (which we explore below), an organizational capability-based explanation is also viable. Consider start-up firms' initial choices regarding governance mode resulting from any reason ranging from serendipity to rational planning and investment.

From those origins, through process investments and learning processes, firms enhance their ability to govern using particular styles. Anecdotal evidence suggests that there may be a reasonable degree of causal ambiguity (loose coupling between cause and effect) associated with "optimally" structuring alliance governance, as we witness a relatively high degree of failure in inter-organizational collaborations (e.g., Dyer, et al., 2004). Consequently, governance structuring meets the classic requirements for being a strategic organizational asset.

\footnotetext{
${ }^{10}$ We do not make claims nor evaluate the optimality of governance capability and use at this stage, as such a study requires a performance evaluation of aligned and misaligned governance situations relative to a benchmark (see Sampson, 2004b and Mayer and Nickerson, 2005 for examples in other contexts).

${ }^{11}$ In complementary efforts, the prior literature has shown that firms can build capabilities through collaboration (Kale, et al., 2000), and that prior general collaborative-, partner specific-, and technology specific-experience positively impact the performance of their inter-organizational relationships (Zollo, et al., 2002).
} 
One important contributor to heterogeneous governance capabilities is suggested by theories of organizational learning in that firms will differ in their ability to acquire, retain, and recall knowledge, resulting in learning curves with different slopes (e.g., Levitt and March, 1988; Walsh and Ungson, 1991), ${ }^{12}$ reinforcing the effect of firms' different levels of experience with various alliance governance modes. A powerful contributor to organizational learning is the extent of organizational memory. While the literature has proposed different loci of alliance knowledge repositories within the firm, such as dedicated alliance departments (Kale et al., 2002) and formal contracts (Mayer and Argyres, 2004), organizational investments in building repositories of knowledge (and their ability to effectively retrieve and extend such knowledge) are important determinants of organizational learning.

There may be a host of other managerial investments necessary to develop a competence in governing different modes of collaborative alliances. Firms must be able to identify, recruit and retain partners willing to engage in collaborations of a particular type, as well as structure transactions appropriate for firm and partner capabilities (Dyer, et al., 2004). Moreover, developing governance capabilities depends on having a mutually supporting organizational design - e.g., hiring scientists and providing them with incentives aligned with projects to be commercialized via particular collaborative forms.

Investments in governance capabilities can also lead to a selection effect wherein a firm would be more likely to select future projects based on its existing governance capabilities; e.g., a firm with a capability in doing licensing deals may choose future projects with a higher likelihood of resulting in a licensing deal. This project selection effect, combined with the organizational learning and investments in organizational structures and resources, suggests that governance capabilities can influence a firm's portfolio of collaborative choices.

A second explanation for the persistence in use of governance capabilities is rooted in contractual origins, as developed in Argyres and Liebeskind's (1999) article on governance inseparability. Using path dependence arguments, these authors argue that firms' ability to choose governance structures may be limited and shaped by governance use in prior time periods. There might be two major reasons for this effect. First relatively long-lasting organizational contractual commitments may perpetuate governance persistence. Particularly for start-ups, offering longer term contracts and/or contracts with broader scope may be necessary to entice would-be collaborators. Such contracts may be also necessary to induce parties to make relatively specific investments (in the sense of exposing themselves to opportunism hazards) necessary for cooperative commercialization. Consequently, governance adjustments may be difficult to execute in the face of contractual commitments.

12 Organizational learning and experience have also been correlated with high performance in collaborative relationships (Anand and Khanna, 2000; Sampson, 2005). 
A relevant second mechanism leading to governance inseparability is the pressure to preserve contractual uniformity across the innovators' collaborative partners. This might be important, even if such contracts span technological or other domains, as parties to a transaction may care not only about the terms of their contract, but also how their terms compare to others contracting with the same innovating start-up (a good example of the phenomenon is employment contracts within a department of an organization). Both these mechanisms can lead to governance inseparability — and the resulting effect of path dependence in governance modes. Therefore, for both organizational governance capability and governance inseparability reasons, we propose:

- H2: Firms' governance capabilities positively influence their current portfolio choice of collaborative modes.

\section{Valuation implications}

We end by discussing the valuation effects associated with firm investments in governance capability development. What are the implications of pursuing paths that diverge from existing capabilities? In particular, as firms consider the development of new capabilities, are there rewards or penalties associated with investing in new methods of collaboration?

Collaborative capability development might be necessary in the long-run, but requires short-run investments in order to develop these governance competencies. We are interested in understanding the degree to which capability investment by managers and recognition of this investment by investors is reflected in firms' valuations. An example of this phenomenon is Abgenix, a biotechnology innovator that had a history of licensing its 'xenomouse' technology to pharmaceutical firms in an arm's-length 'hand off' strategy. In order to develop downstream commercialization capabilities, the firm needed to pursue a shift in its strategy to include co-development, which in the short-run forced the firm to trade off a steady royalty stream from arm's-length licensing to develop its commercialization capabilities. Top management of the company worried that this shift in business model would receive a negative shareholder reaction, and weighed that factor when considering the business decision (Harvard Business School case 9-501-061).

The prior literature has discussed the valuation impact of collaboration events generally (e.g., Chan, et al, 1997; Das, et al., 1998), suggesting that collaborative activity has a positive impact on firm performance. While some of these studies have (lightly) touched on the question of how heterogeneity in cooperation mode leads to a differential impact on valuation, the valuation effect of divergence from existing collaboration governance capabilities, to our knowledge, has not been addressed. We expect that the strategic choice of pursuing a particular mode entails a tradeoff between two competing effects: first, 
the extant capability stock associated with a given mode influences the propensity of the firm to use that mode; second, investments in new capabilities may be beneficial in the future, but costly today.

Since investments are inherently risky, we might expect that the capital markets may not immediately take into account the full value associated with the choice to invest in a new capability. This may occur either because markets are myopic, or because they hold a different perception of the risk associated with firm choices. ${ }^{13}$ Thus, we would expect that firms which deviate from their existing capability stock in order to pursue investments in new governance capabilities to receive lower valuations.

Since a negative reaction of the capital markets to new capability investment is dependent upon the markets perceiving greater risk associated with this investment than the firm managers themselves, we might further believe that in situations where markets are less risk averse, the differential between the market's risk perception and that of managers will be reduced. We propose that such a situation occurs in 'hot' markets, where markets are generally less risk averse and more forgiving of managerial investments in new capabilities (Ritter, 1984). Based on this discussion, we offer the following hypotheses:

- H3a: Selecting cooperative modes that result in deviations from existing governance capabilities will lead to lower firm valuations.

- H3b: The effect of governance capability deviations on firm valuation is moderated by hot vs. cold external finance conditions.

\section{Research Design}

To address the correlates and consequences of heterogeneous modes of collaborative R\&D commercialization, we chose an empirical setting which satisfies two requirements. The empirical context would ideally exhibit both variation among cooperative forms of organization as well as non-existent or infrequent self-commercialization. ${ }^{14}$ The biotechnology industry is close if not ideal in fulfilling these criteria, as the economics of the industry are such that collaborative commercialization with larger pharmaceutical firms is often the dominant choice, yet there is considerable variation in the way in which such transactions are organized and governed.

\footnotetext{
${ }^{13}$ At least two other mechanisms have been proposed in the literature for altered firm valuations resulting from changing organizational strategies. Stein (1989) argues that myopic managerial behavior (in the context of managerial corporate earnings manipulation) can be perpetuated, even when capital markets are operating efficiently as a result of a prisoner's dilemma effect. Another mechanism (one in which managerial information asymmetries is not relevant and also does not rely on market inefficiencies), involves managers and firms updating their beliefs about their own skills and capabilities over time through sequential options-based investments (Bernardo and Chowdhry, 2002). In this second mechanism, it is the volatility of capability uncertainty (rather than the resources themselves) which leads to differences in valuation.

${ }^{14}$ For an analysis of the determinants of commercialization strategy between self commercialization and cooperative development, see Gans, et al. (2002). For an analysis of the timing of collaborative commercialization between innovators and more established firms, see Gans, et al. (2006).
} 
We examine organizational governance capability and transaction cost based explanations for heterogeneous forms of collaboration intensity and conduct analyses at both the firm-year level in a panel data set and at the transaction level in an underlying, associated data set. All analyses at the firm level employ firm fixed effects OLS specifications, thereby estimating effects through within-firm, across-time variation to mitigate the risk that unobserved heterogeneity across firms in the sample are driving the results. The transaction level analysis employs multinomial logit regressions (with standard errors clustered by firm), thereby modeling alternative choices of organizing a deal as a function of firm capability and transaction cost measures. This section discusses the data construction and provides a description of the variables used in the empirical analysis.

\section{A. Data sample}

To construct a firm-year panel, we begin by randomly sampling a set of biotechnology firms. We use the Thomson One Banker database to create a list of all firms in SIC codes 2833-2836 that are located in the U.S. and have conducted an IPO ${ }^{15}$ in the past 25 years. From this list of 468 firms, we randomly select 117 firms that we use as the basis for our sample. By using the CorpTech and Hoover's databases, combined with Lexis-Nexis news article searches, we determine the founding and dissolution dates for each firm. Dissolution is defined as any situation where the firm ceases to exist either because it is acquired, or because it goes bankrupt or dissolves for other reasons. We obtain yearly data for our sample of firms from the year of founding to the year of dissolution (or 2004 if the firm is still in existence).

The primary source for our cooperation variables is the Recombinant Capital (ReCap) RDNA Alliances database. For each firm in ReCap, there is a full listing of all cooperation events (alliances and acquisitions) the firm has been involved with throughout its history. For each cooperation event, we download and code a relevant set of information associated with that event. In particular, we note whether the firm was a 'client' or 'R\&D' partner in the alliance, the name of the partner, the stage at signing, a subject description of the alliance, and a variety of contractual characteristics associated with the alliances, including whether there is an equity component associated with alliance, and whether the alliance included a licensing component. Our sample is composed of randomly selected biotechnology firms drawn from the set of $R \& D$ innovators, which allows us to make inferences about $R \& D$ commercialization from the innovator's perspective. The cooperation data are organized both at the transaction level as well as aggregated to the firm-year level for the empirical analysis. We obtain cooperation data for 91 firms and 786 firm-years, spanning 1,200 collaborative transactions (due to various missing data, the regressions often include fewer observations).

\footnotetext{
${ }^{15}$ While we select firms that have conducted an IPO in order to ensure sufficient availability of firm-level data, in constructing the firm-year panel we obtain data for all years, both public and private.
} 
Next, we code the particular therapeutic classes associated with our sample of alliances and firmyears. For each alliance, we use the alliance subject information to allocate the alliance to one or more of 24 therapeutic classes. Virtually all of the alliances are coded as belonging to only a single class. We then analyze SEC documents (S-1s and 10-Ks) to determine the therapeutic classes in which the firm itself is involved during each observation year. This is generally done by looking through the 'Company Overview' or 'Our Business' sections of the documents, isolating keywords, and cross-referencing with drug pipeline descriptions if available. The appendix provides a detailed discussion of our classification scheme.

We obtain patent data, VC data, and firm-level data for our panel by utilizing a variety of sources. For the patent data, we use the United States Patent and Trademark Office (USPTO) website to identify all patents granted to our sample of firms. We then use the National Bureau of Economic Research (NBER) patent database (Hall, Jaffe and Trajtenberg, 2001), which contains patent information through 1999, combined with a proprietary patent database at the National University of Singapore that contains fields similar to the NBER data, but updated through 2004, to generate a variety of patent-based measures for our sample. Our primary source for the VC data is VentureXpert. We retrieve information on all VC funding events such as valuation and funding amounts for each of the firm-years in our sample. Finally, we obtain firm-level information such as firm size and market capitalization through a combination of CorpTech, Hoover's, SEC documents and Compustat.

\section{B. Variables}

Addressing our research question calls for constructing measures of outputs (collaborative organizational form and firm valuation) as well as inputs (organizational capabilities, transaction costs, and controls). We describe the variables used in our analysis in this section. Definitions, means and standard deviations of these variables are provided in Table 1, and a correlation matrix of the independent variables is provided in Table 2.

\section{Dependent variables}

As previously discussed, we are primarily concerned with analyzing collaborative mode choice intensities at the firm level since top managers are concerned with both the organization of particular transactions as well as the governance of their firm's collaborative portfolio (we describe our transaction level analysis shortly). Our primary collaborative mode dependent variables at the firm-year level of analysis are equity-use intensity and license-only intensity. The denominator for each of these variables is the total number of alliance events in a given firm-year where the focal firm is the R\&D partner. Focusing on these alliances allows us to confine our discussion to situations in which the firm itself is the 
innovator. The numerator of the equity-use intensity dependent variable (mean $=0.17$ ) is the total number of alliances during the given firm-year in which equity is a component of the deal. The numerator of the license-only intensity dependent variable (mean $=0.21$ ) is the number of pure licensing alliances during the given firm-year. ${ }^{16}$ These two variables operationalize the concept of managers' portfolio choice of collaboration governance in a fundamentally different way than much of the existing literature on the topic, which has sought to predict the governance of a particular transaction.

In order to compare our analysis at the firm portfolio level to a transaction-level analysis, we employ a dependent variable that accommodates multiple discrete outcomes in the context of multinomial logit regressions at the transaction level of analysis. The dependent variable $=1$ if a deal involves equity use and $=2$ if a deal employs arm's-length licensing only (and $=0$ otherwise).

In addition to analyzing the incidence of equity and license-based collaboration modes, we examine their performance impact as measured by firm valuation (as well as the associated impact of firms' deviations from their historic experience in structuring collaborative transactions, their governance capabilities). We therefore construct firm valuation (mean $=\$ 374 \mathrm{M}$ ) as a dependent variable. For firms' private years, we use the valuation at the most recent round of venture funding, while for public years we use market capitalization. The variable is meant to capture the overall value of the firm as assessed by its shareholders. We transform firm valuation by taking the natural log to address its skewed distribution.

\section{Independent Variables}

Our independent variables are organized into three set of variables: firm governance capability measures, transaction cost measures, and control variables. The first set of variables measure firms' experience in collaborating and structuring collaborative deals. Equity-use deal stock (mean $=0.88)$ and license-only deal stock (mean $=1.25$ ) represent the total number of equity or license-only deals the focal firm has been involved with (in a given firm-year) since firms' inception. Such experience likely captures a range of governance capabilities ranging from recruiting collaborative partners to negotiating and structuring agreements of a particular type with them.

To explore how reinforcing or deviating from firms' prior collaborative mode experience affects its market valuation, we introduce two additional variables: equity-use deviation (mean $=-0.02$ ), and license-only deviation (mean $=0.07$ ). For a particular mode, the divergence variable is constructed by taking the difference between the percentage of all prior cooperation events utilizing a particular mode (based on the stock of such experience), and the percentage of all current year cooperation events

\footnotetext{
${ }^{16}$ These two dependent variables are not simply the mirror image of each other, as the numerator of equity-use intensity excludes any non-equity form of R\&D collaboration, while the numerator of license-only intensity excludes deals with any component other than a pure supply agreement.
} 
utilizing that mode. As well, because the divergence terms are potentially non-linear, we also include the square of these divergence terms in our valuation regressions.

A second set of variables relate to transaction cost measures, which are aggregated to the firmyear level. Two variables are concerned with firm and alliance scope. The first, therapeutic scope (mean $=2.27$ ), is a count of the number of therapeutic areas the firm is involved in during the given firm-year. Higher values of therapeutic scope may proxy for elevated bureaucratic and administrative structure necessary to govern firms' existing $R \& D$ and commercialization activities. While there may be a minimum organizational administrative structure regardless of a firm's span of activities across therapeutic areas, it is likely that bureaucratic structure increases with firms' therapeutic scope due to the need for program-specific governance. With a fixed supply of managerial resources and attention (at least in the short term) broader therapeutic scope may proxy for higher transaction costs associated with further hierarchical organization. ${ }^{17}$

The second transaction cost measure, average deal scope (mean $=0.99$ ), is the number of business categories spanned by an average deal in a given firm-year excluding equity-use and licensingonly deals (counting those categories would artificially increase the average deal scope correlation with the main dependent variables, equity-use intensity and licensing-only intensity). The average deal scope variable aims to capture more complex and/or ambitious collaborative transactions. In such cases, the range of outcomes may be more variable, and so contracting on possible contingencies may be more onerous (or not possible). High transaction costs may therefore drive firms operating under more complex transaction environments to choose more hierarchical governance structures such as equity-based collaborative arrangements.

The threat of innovator expropriation in the context of technology transfer and contracting may be mitigated by a strong intellectual property position. The conventional wisdom is that the appropriability regime for innovators via formal intellectual property rights is strongest in the health science and chemical sectors (e.g., Levin, et al., 1987). Yet even within the biotechnology sector, there has been a substantial rise in patenting rates, even outstripping the increase in overall patenting rates over the past 20 years (e.g., Kortum and Lerner, 1999), suggesting that patent awards within relatively strong intellectual property regimes is meaningful. Consequently, we construct the variable, patent stock (mean $=9.73$ ), which counts the total stock of patents held by the firm up to a given firm year.

The final transaction cost variable, prior partner experience $($ mean $=0.17)$, represents the number of alliance events prior to that firm-year involving the firm's current year partners. This variable proxies

\footnotetext{
${ }^{17}$ A learning interpretation of the therapeutic scope variable is also possible, as organizational adjustment and learning associated with firms' changing therapeutic scope may also be substantial. We thank Kyle Mayer for raising this alternate interpretation.
} 
for the extent to which past bilateral collaborations may lower expropriation hazards due to reputation effects and the potential for future deals in enforcing discipline on opportunism threats between parties in the current period.

Finally, we include a number of control variables in the analysis. The variable new therapeutic area dummy $($ mean $=0.17)$ indicates whether a firm undertook an alliance during a given year involving a therapeutic area in which it had not previously conducted an alliance (the therapeutic areas are based on our previously described 24-category classification scheme). This variable is lagged two years, so that we can examine the effect of entering a new area via an alliance. The variable controls for the possibility that firms will systematically choose one governance form over another when entering into a new therapeutic area. For example, with no established experience in a given domain, firms may have to offer an equitystake inducement in order to interest a potential collaboration partner.

A second control variable aims to capture firms' access to external resources via affiliation with venture capitalists. We construct the variable VC amount invested (mean $=\$ 11.05 \mathrm{M})$, which is the total amount of equity invested in the firm up to a given firm-year. The VC literature has stressed the importance of network access for start-up resource acquisition (e.g., Hellmann and Puri, 2002; Hsu, 2004), and so higher levels of VC amount invested may be correlated with firms' external access to organizational resources. The literature has also highlighted the organizational structure and influence by venture capitalists (e.g., Gomper and Lerner, 1999) which may impact start-ups' collaborative commercialization practices.

A final set of control variables control for firm age, stage of business development, and business environment effects. The variable firm age (mean $=8.24$ years), number of employees $($ mean $=552.4)$, a dummy for whether the firm is public (mean $=0.61$ ), a control for the stage of firms' alliances (discovery stage projects $[$ mean $=43.11$ ], the number of alliances in which the firm is still in the 'discovery' stage), and a measure of environmental munificence of the biotechnology industry, the Lerner Index level [mean $=4.81]^{18}$. Due to the skewed distribution of the independent variables (except for the Lerner index level), we add one to all continuous variables and take a natural log transformation of the underlying variable.

\section{Empirical Results}

The empirical analyses are organized to examine organizational governance capability and transaction cost based explanations for observed variation in inter-organizational collaborative mode, as well as firm valuation implications of collaborative governance choice. We first examine correlates of

\footnotetext{
${ }^{18}$ The Lerner index is available through 1999 (see Lerner, 1994 for a description of the index). For 2000-05 we use estimates of the index which we construct by regressing the Lerner index on the Nasdaq Biotechnology Index (NBI) for 1993-99 (the available overlapping years), then using the estimated coefficients of the regression, combined with actual values of the NBI, to generate the predicted values.
} 
equity-use intensity and licensing-only intensity in firms' portfolio of collaborative activities at the firmyear level of analysis. We then compare these results to a transaction level analysis in which the decision to organize a given deal is modeled as a choice among equity-use, licensing-only, and other forms of cooperative commercialization. In this context, we investigate the importance of governance capability and transaction cost explanations in explaining transaction level deal design choice. Finally, returning to the firm level of analysis, we explore shareholder reaction (via firm valuations) to current period deviations from historic capabilities of organizing inter-organizational collaborations. Each analysis is discussed in turn.

\section{A. Firm level equity-use intensity}

We begin the empirical analysis by examining the incidence of equity use among firms' collaborative alliances. The dependent variable we analyze in Table 3 is the fraction of firms' deals in a given firm-year involving an equity component. Each of the specifications here and in all the firm level analyses contain firm fixed effects to control for (time invariant) unobserved firm heterogeneity.

In the first column of the table, we examine the impact of prior experience in conducting equity and arm's length licensing deals on equity-use intensity. In this simple specification, license-only deal stock is negatively associated with equity-use intensity in the current firm-year (though when control variables are added, the coefficient on license-only deal stock becomes insignificant). More importantly, the equity-use deal stock variable is positively associated (at the $1 \%$ level of statistical significance) with a higher fraction of equity deals in the present, which suggests that firms build a governance capability in structuring or organizing such deals (lending support for $\mathrm{H} 2$ ).

This result is maintained and reinforced in the second column of Table 3, which adds our full slate of control variables: new therapeutic area, VC amount invested, firm age, number of employees, discovery stage projects, and Lerner index level. The new therapeutic area dummy is positively associated with equity-use intensity at the 5\% statistical significance level, suggesting that firms, when they enter into new therapeutic areas in which they have no prior experience, tend to do so via equity use. It may be the case that innovators have to give up an equity stake in order to induce commercialization partners to participate (though the significance of this variable disappears in the fully-specified fourth model).

A third column retains the set of control variables but examines the role of transaction cost variables in explaining variation in equity-use intensity. We examine four variables which proxy for transaction costs: therapeutic scope, average deal scope, patent stock, and prior partner experience. The first two measures consider the operations of the firm in a given year with respect to the number of distinct therapeutic segments and in the number of business categories spanned by the firm's average deal. Higher values of therapeutic scope may proxy for added administrative costs associated with 
governing additional collaborative relationships. More complex collaborative transactions may involve more intensive (and costly) governance arrangements, a concept average deal scope aims to capture. High transaction costs may therefore drive firms operating under more complex transaction environments to choose more hierarchical (equity-based) governance structures for their collaborations. While the therapeutic scope variable is not estimated with a significant coefficient, the average deal scope variable is positive and significant, suggesting that broader business category deal scope is associated with equityuse intensity. While we are not able to test the effect of technological scope and overlap between collaboration partners using patent characteristic data (as in Sampson, 2004b), it would be interesting to do so in future work.

Two additional measures of transaction costs, which proxy for the expropriation threats facing innovating start-ups, are included in column three of Table 3. Prior partner experience proxies for the extent to which past bilateral collaborations may lower expropriation hazards due to reputation effects and the potential for future deals in enforcing discipline on opportunism threats between cooperating parties today. This variable is not significant in the regression. A second measure of expropriation is patent stock (higher patent portfolios proxy for stronger intellectual property positions). Patent stock is estimated with a negative and statistically significant (1\%) coefficient, and together with the average deal scope effect, lends support for $\mathrm{H} 1$ on firm-level contractual hazards and the substitutability of equity use and alternate mechanisms limiting opportunism threats in appropriating value from innovative activity.

When both organizational governance capability and transaction cost variables are entered into a single specification simultaneously together with control variables (as shown in the final column of Table $3)$, the results described in this section are robust. In this fully specified model, both the governance capability variable, equity-use deal stock, and transaction cost variables (patent stock and average deal scope) are significant in explaining the variance in firm equity-use intensity.

\section{B. Firm level licensing-only intensity}

We next examine the incidence of firms' share of deals involving arm's-length contracting (licensing-only intensity) in Table 4. As previously discussed, arm's length technology licensing is an independently interesting organizational governance mode since it entails the choice of foregoing collaborative co-development and equity use. Again taking an organizational portfolio of collaborative mode perspective, we use empirical specification structures parallel to Table 3 (firm fixed effects OLS regressions) to examine the correlates of firms' licensing-only intensity.

Starting with organizational governance capability variables, we find that license-only deal stock is positive and statistically significant at the $1 \%$ level in both a parsimonious specification (column one) and when entered together with the set of control variables (column two). This result is consistent with the 
importance of governance capabilities in structuring and influencing the organization of a firm's current portfolio of collaborative transactions. The negative coefficient on equity-use deal stock in the first specification of Table 4 reinforces this conclusion (though the statistical significance is eliminated in the fully specified model).

The third column of Table 4 examines the importance of transaction cost measures (entered in the specification together with the full set of control variables). While the measure of transaction complexity, therapeutic scope, is not significant, the two measures for limiting opportunism are mixed. ${ }^{19}$ The patent stock variable is not significant, but the prior partner experience measure is positive and statistically significant at the 5\% level. The patent stock results in Tables 3 and 4 suggest that higher stocks of intellectual property may be more important in facilitating equity-based rather than arm's-length collaborative activity.

The positive prior partner experience effect is consistent with the view that licensing activity is enhanced when accumulated trust has been developed between two partners firms. Building on the notion that contracts are necessarily incomplete (in that all possible contingencies cannot be explicitly contracted upon), a literature in alliance activity has stressed the role of trust in enabling licensing activity. The positive prior partner experience effect is also consistent with a bilateral reputation-preserving mechanism in which the focal firm could be investing in the relationship in order to do progressively broader or more valuable deals with the partner organization, and so the cost of defecting on an accumulated bilateral relationship is relatively high. ${ }^{20}$ For these reasons, such prior partner experience mitigates contractual hazards.

Finally, in a specification which includes firm governance capability measures, transaction cost measures, and controls (the final column of Table 4) the key prior results remain robust. In particular, experience and competencies in structuring arm's-length licensing transactions and bilateral cooperation experience with partners (mitigating the threat of opportunism) are associated with higher license-only intensity.

\section{Transaction level analysis of collaborative mode}

The analysis thus far has examined firms' relative use of equity and arm's-length licensing in organizing their collaborative relationships at the firm level of analysis. We now present a parallel analysis at the transaction level of analysis, where an observation is a deal. By using multinomial logit

\footnotetext{
${ }^{19}$ The variable average deal scope is excluded from this specification because by definition, the dependent variable, license-only intensity, is based on deals with scope equal to one.

${ }^{20} \mathrm{We}$ are not able to test this explanation in any detail because doing so would require adopting a potentially collaborating dyad as the unit of analysis and characterizing average deal terms over time (including counterfactual deal terms between organizations that did not collaborate in an observation period).
} 
regressions, we examine three alternative modes of organizing a collaborative transaction: equity-use, licensing-only, and other collaborative modes (the last of which represents the baseline category in the multinomial logit). The results, in which the reported standard errors are clustered by firm in the analysis, are presented in Table 5 .

In a first specification, we examine governance capability measures together with the set of firmlevel controls and deal-level controls. While the former controls are the same as those used in the prior tables, the latter variables include a set of four deal stage dummies, and a set of five therapeutic area dummies. All estimates in this table should be interpreted relative to the baseline collaborative mode, nonequity co-development. For example, the negative and significant coefficient on Lerner index level associated with equity-use (but not license-only) suggests that relative to non-equity co-development, equity is used more sparingly in less munificent external funding conditions. The main result of the first specification is that equity-use deal stock is positively correlated with transaction equity-use (but not with license-only use), and license-only deal stock is positive and significantly correlated with deal level license-only use (but not equity-use-and indeed the correlation is negative and significant) after controlling for various firm and deal variables. These main results are robust in the fully specified model in column three.

The second specification retains the same set of control variables but instead focuses on transaction cost variables. ${ }^{21}$ As before, the therapeutic scope variable proxies for deal complexity and associated contracting challenges/opportunism. The variable is positively associated with license-only but not with equity-use, which is somewhat inconsistent with the concept that more complex transactions pose contractual difficulties due to more variable potential outcomes. In the fully specified model (column three), however, therapeutic scope is no longer significant for either dependent variable outcome. The final specification of Table 5 puts all these effects together, and the picture that emerges reinforces the importance of organizational governance capability (rather than transaction cost considerations) in explaining observed heterogeneity in organizing collaborative relationships.

\section{Firm valuation and cooperative mode}

We conclude the empirical analysis by examining valuation implications of both organizational governance capabilities as well as firm deviations from their historic capabilities. We do this by returning to the firm level of analysis in Table 6 . The valuation measure spans both private valuations (assigned by

\footnotetext{
${ }^{21}$ Note that our transaction cost variables are constructed at the firm level. We experimented with a deal breadth measure that is analogous to the average deal scope variable. We would have to modify this variable for the transaction level multinomial logits because one of the outcomes is license-only, which by definition has a deal scope of one. To preserve consistency in the empirical tables, we therefore used only firm-level transaction cost variables.
} 
VCs) and valuations when the firm is public, as measured by market capitalization (the product of publicly-traded share price and number of shares outstanding). While we pool the private and public valuation observations in the reported regressions, the results are broadly consistent with disaggregated results separating private and public valuations.

We first examine the impact of equity-use deal stock and license-only deal stock, together with deviations from historic average levels of equity and arm's-length license use in the first column. Equityuse deal stock is positively associated with firm valuation in this specification, as there is upside potential with these deals, which is an important part of the option value concept associated with equity structuring. As further controls are added in the table, equity-use deal stock becomes less statistically significant, however. License-only deal stock is consistently associated with firm valuation, perhaps because shareholders perceive less downside risk associated with this form of cooperation.

License-only deviation, which is the normalized deviation of current period arm's-length license use relative to historic levels of such activity, is consistently negatively-estimated in the regressions. This suggests that lower levels of current period licensing relative to historic levels is associated with lower firm valuations. The included squared term of license-only deviation is also negative (and statistically significant at the $1 \%$ level), which supports a linear effect on firm valuation, reinforcing the main licenseonly deviation effect. The analogous equity-use deviation variables are not significant across the regressions.

From an economic equilibrium standpoint, these results are provocative. One might expect that alternate collaborative commercialization modes which accomplish a similar function might be neutral from the standpoint of firm valuation. If technology licensing represents a relatively stable income stream to the innovating firm, and equity-based transactions represent a higher (though more variable) expected payoff, there should be a portfolio of some combination of these two types of collaborative activity which should be equivalent in valuation relative to a portfolio constructed of deals of entirely one type or the other. Firms may have to invest in acquiring new governance capabilities if they do not already possess them (over a longer time horizon, investing in developing the capability would ideally pay off), but the estimates above suggest that shareholders seem to value arm's length licensing capabilities more than equity governance competencies in this data set. In addition, higher intensities of licensing transactions (relative to historic such activity) is positively associated with value, though the same is not true for equity-use deviations.

The second specification of Table 6 suggests that VC amount invested is negatively associated with firm valuation, although in the fully-specified model (column three), the VC effect is not statistically different than zero. In addition, larger firms (as measured by employees) have higher valuations as do 
firms with a large number of discovery stage projects. The remainder of the second specification of the table examines transaction cost factors, but none of these variables are statistically significant.

The third specification of Table 6 adds in the Lerner index level, along with interaction terms of this measure with the license and equity-use deviation measures. The primary capability variables, and particularly the results on licensing previously discussed, remain robust in this specification. A positive value of the Lerner index level suggests, as expected, that more munificent funding environments are associated with higher valuations. The Lerner index level interaction term with licensing-only deviation suggests that in 'hot' biotechnology financial markets, the negative impact of license capability deviation (conducting fewer licensing deals in the present as compared to historical norms) is attenuated, consistent with hypothesis $3 \mathrm{~b}$.

Taken as a whole, Table 6 suggests that (1) arm's length licensing is tied to firm valuation (perhaps more so than equity-use), and (2) higher intensities of licensing transactions (relative to historic such activity) is positively associated with valuation, with this effect being moderated in 'hot' markets. ${ }^{22}$

\section{Conclusion}

This paper examined the determinants of start-up firms' strategic choices in organizing their inter-firm collaborative R\&D relationships. We focused our analysis on both the firm and transaction levels of analysis, taking into account the effect of transaction cost considerations and firm governance capabilities on choice of governance mode. Because managers might be expected to take into account the impact of governance decisions on the firm's portfolio of collaborative activity (in addition to considering contractual hazards of individual transactions), examining the impact of transaction and firm-level factors at both levels provides richer insight into the factors impacting governance choice. While an emerging literature has recognized the importance of taking a multi-theoretical approach to understanding the governance of inter-organizational collaborations, the majority of these studies are focused on understanding the drivers of transaction-level governance. This study represents a complementary perspective by also examining the determinants of the relative intensities of firms' collaborative organizing choices. ${ }^{23}$

\footnotetext{
${ }^{22}$ While we can observe the valuation impact of divergence in collaborative mode choice, we cannot disentangle the impact of managerial choice from market recognition of that choice. A negative valuation associated with capability divergence can result because managers have made a choice that is not fully rational and markets (efficiently) recognize this choice, or from managers making a fully rational choice and markets (inefficiently) failing to recognize this. Confirmation of $\mathrm{H3a}$, however, does allow us to reject the hypothesis that managers make optimal decisions and at the same time these decisions are efficiently reflected in market valuations. As well, regarding the possibility of reverse causality (changes in governance form in response to changes in firm valuation), our panel data techniques in which annual data are most prevalent (for firms' public valuations) mitigates this concern.

23 There can be a downside to persistence of governance-use in inter-organizational collaborative commercialization strategy. Dyer, et al. (2004) suggest this possibility when they point out that managers may be tempted to structure
} 
The empirical results are broadly consistent with the idea that transaction cost considerations and firm capabilities both have important roles in the choice of governance mode. Increasing levels of contractual hazards tend to be associated with more hierarchical governance structures, with equity use serving as a substitute for factors that may mitigate potential threats of expropriation. Beyond transaction cost considerations, we find strong results for the role of firm governance capabilities in determining cooperative commercialization mode choice. Prior experience with particular collaborative modes has a significant influence on choice of mode in the present, supporting resource-based theories of capability development that draw on ideas of path dependence and organizational learning through prior experience.

We also explore the effects of cooperative mode choice on firms' valuation. The results suggest that market valuation is correlated with both firms' experience in cooperative mode and firms' deviations from prior historical levels of governance experience for arm's length licensing use (and to a lesser extent, equity-use). The latter finding implies that there is heterogeneity in the way markets react to firm investments in developing new collaborative capabilities. Investments in new governance capabilities must therefore trade off the potential benefits associated with accessing new modes with the learning and capabilities associated with prior collaborative events.

Several interpretational issues which may impact the study's conclusions merit discussion. A first set relates to possible sample selection issues associated with the data set. There are two potential sources of selection bias from our sample. First, we select firms and observations conditioning on (eventual) cooperation by innovators. Second, the sample is conditioned on firms that have conducted an IPO. On the first issue, while it is difficult to quantify the extent of result bias resulting from analyzing a data set composed of cooperative events, the results should appropriately be interpreted as conditional on cooperation. Nonetheless, we speculate that the results are probably not entirely dissimilar to estimates that might be attained from an ideal data set which mirrors the underlying distribution of commercialization activity in the biotechnology industry. We base this belief on the observation that selfcommercialization in biotechnology is relatively rare due to the joint condition of strong intellectual property protection (mitigating risks of expropriation in the course of collaboration) coupled with the relatively high costs associated with assembling the relevant complementary assets (e.g., navigating the drug approval process) needed for self commercialization. Consequently, the rate of collaborative commercialization between biotechnology and pharmaceutical firms is high.

While the biotechnology industry context is an attractive one for analyzing the variation among cooperative modes since there is substantial heterogeneity in the organization and governance of

all their transactions according to their experience and knowledge-base. Making such an inference would involve defining aligned vs. non-aligned governance situations, and examining the consequences of such situations. For good recent examples of such assessments, see Sampson (2004b) and Mayer and Nickerson (2005). For a discussion on prior experience and learning myopia more generally, see Levinthal and March (1993). 
collaborative relationships, it is more difficult to make global generalizations from this study. The methodology and measures we employ here do not importantly depend on industry context; however, we hesitate to make general inferences from these results without further studies investigating potential interactions and endogenous decisions between the business and economic environment and interorganizational R\&D collaboration mode. Such future studies which cover different industry and crossindustry contexts would both be welcome.

The second selection issue concerns conditioning the sample on firms that (ex-post) conducted an IPO (even though we collect information about firms' pre- and post-IPO activity). We do this in order to ensure availability of adequate data (a motivating factor for most of the papers in this literature). Our sample is therefore likely to contain higher performing firms relative to the underlying population of biotechnology firms (though due to the pervasiveness of raising funds from the public markets in this industry, the bias may not be severe-Sorensen [forthcoming], for example, finds that the average biotechnology company has a $39 \%$ greater probability of going public relative to an average company in another technology-intensive sector). The questions then are whether higher quality firms employ a different mix of cooperative forms relative to the biotechnology population, and whether the explanatory variable estimates apply similarly to the underlying distribution of firms. While we acknowledge the firm quality issue as a caveat to the study, we leave the importance of this selection issue to future research.

An additional limitation of our sample is that the data are less complete for the private years than for the public years. Private firm-year data is generally difficult to obtain, and our data collection efforts have been fairly exhaustive given the constraints of the research design and available data sources. The use of a firm-year level of analysis, combined with controls for public years, however, likely mitigates some of the issues associated with the reduced number of private-year observations. The effect of this skew is thus likely to be a reduction in the statistical power of our results rather than a bias in the coefficients, however.

A final set of limitations and interpretational issues arise from the level of analysis in the paper. We purposefully aggregate transaction-level data to the organizational level of analysis in order to study organizational-level phenomena. The tradeoff to such an approach is sacrificing certain transaction-level elements, such as detailed contractual information. While we experimented with coarse contractual level variables available to us, such as the presence of upfront payments, the lack of systematic contractual data across the transactions prohibit us from drawing strong conclusions about the role of contracting on the choice and consequence of collaborative governance mode. While computationally onerous, future studies in this domain may consider joining such contractual-level detail with a relatively large sample of cooperative commercialization data. 
A number of additional avenues exist for future research in this area. Future research might build on the results of prior experience with collaborative $R \& D$ organizing modes by exploring in more detail the conditions under which governance capabilities are developed. Are there organizational factors that moderate or enhance the development of these capabilities? To what extent does organizing experience hinder firm investments in new ways of organizing transactions in shifting business environments? In what ways do top management characteristics shape the organization of collaborative transactions? With respect to the valuation issue, future research might address the degree to which markets do or do not appropriately value capability divergence. Do negative coefficients on organizing mode in the valuation regressions suggest that markets are efficiently recognizing inefficient choices, or are markets simply being myopic and not recognizing the value associated with investing in new capabilities?

The current study accomplishes two objectives. First, it deepens our understanding of the drivers of variation in firms' collaborative R\&D choices, choices which can have a host of important internal resource allocation and strategy implications for both innovator and partner firms. As well, it demonstrates that organizational capabilities of structuring collaborations can be tied to firm valuation, as can deviations from such capabilities. 


\section{REFERENCES}

Anand, B.N. \& Khanna, T. (2000). "Do Firms Learn To Create Value? The Case of Alliances." Strategic Management Journal, 21: 295-315.

Argyres, N.S. \& Liebeskind, J.P. (1999). "Contractual Commitments, Bargaining Power, and Governance Inseparability: Incorporating History into Transaction Cost Theory." Academy of Management Review, 24: 49-63.

Arora, A., Fosfuri, A., \& Gambardella, A. (2001). Markets for technology: Economics of Innovation and Corporate Strategy, Cambridge, MA: MIT Press.

Bernardo, A.E. \& Chowdhry, B (2002). "Resources, Real Options, and Corporate Strategy," Journal of Financial Economics, 63: 211-234.

Chan, S.H., Kensinger, J.W., Keown, A.J., \& Martin, J.D. (1997). "Do Strategic Alliances Create Value?" Journal of Financial Economics, 46: 199-221.

Coleman, J.S. (1988). "Social Capital in the Creation of Human Capital," American Journal of Sociology, 94: S95-S210.

Colombo, M.G. (2003). "Alliance Form: A Test of the Contractual and Competence Perspectives." Strategic Management Journal, 24: 1209-1229.

Das, S., Sen, P.K., \& Sengupta, S. (1998). "Impact of Strategic Alliances on Firm Valuation.” Academy of Management Journal, 41: 27-41.

Dyer, J.H., \& Singh, H. (1998). "The Relational View: Cooperative Strategy and Sources of Interorganizational Competitive Advantage.” Academy of Management Review, 23: 660-679.

Dyer, J.H. (2000). Collaborative Advantage: Winning Through Extended Enterprise Supplier Networks, New York, NY: Oxford Press.

Dyer, J.H., Kale, P., \& Singh, H. (2004). "When to Ally and When to Acquire." Harvard Business Review, 82(7-8): 108-115.

The Economist (2005). “A Market for Ideas: a Survey of Patents and Technology,” Oct 22.

Eisenhardt, K.M., \& Schoonhoven, C.B. (1996). "Resource-based View of Strategic Alliance Formation: Strategic and Social Effects in Entrepreneurial Firms." Organization Science, 7: 136-150.

Filson, D., \& Morales, R. (2006). "Equity Links and Information Acquisition in Biotechnology Alliances." Journal of Economic Behavior and Organization, 59: 1-28.

Gans, J.S., Hsu, D.H., \& Stern, S. (2002). "When Does Start-up Innovation Spur the Gale of Creative Destruction?" RAND Journal of Economics, 33: 571-586.

Gans, J.S., Hsu, D.H., \& Stern, S. (2006). "The Impact of Uncertain Intellectual Property Rights on the Market for Ideas: Evidence from Patent Grant Delays.” Wharton School \& Kellogg working paper. 
Gomes-Casseres, B., A.B. Jaffe, \& J. Hagedoorn (forthcoming). "Do Alliances Promote Knowledge Flows?" Journal of Financial Economics.

Gompers, P. \& Lerner, J. (1999). The Venture Capital Cycle. Cambridge, MA: MIT Press.

Gulati, R. (1995). "Does Familiarity Breed Trust? The Implications of Repeated Ties for Contractual Choice in Alliances." Academy of Management Journal, 38: 85-112.

Gulati, R. (1998). “Alliances and Networks.” Strategic Management Journal, 19: 293-317.

Gulati, R. \& Singh, H. (1998). "The Architecture of Cooperation: Managing Coordination Costs and Appropriation Concerns in Strategic Alliances.” Administrative Science Quarterly, 43: 781-814.

Hagedoorn, J. (2002). "Inter-firm R\&D Partnerships: An Overview of Major Trends and Patterns Since 1960.” Research Policy, 31: 477-492.

Hall, B.H., Jaffe, A.B., \& Trajtenberg, M. (2001). "The NBER Patent Citations Data File: Lessons, Insights and Methodological Tools." NBER working paper 8498.

Hellmann, T., \& Puri, M. (2002). "Venture Capital and the Professionalization of Start-up Firms: Empirical Evidence.” Journal of Finance, 57: 169-197.

Hsu, D.H. (2004). “What do Entrepreneurs Pay for Venture Capital Affiliation?” Journal of Finance, 59: 1805-1844.

Kale, P., Singh, H., \& Perlmutter, H. (2000). "Learning and Protection of Proprietary Assets in Strategic Alliances: Building Relational Capital.” Strategic Management Journal, 21: 217-237.

Kale, P., Dyer, J.H., \& Singh, H. (2002). "Alliance Capability, Stock Market Response, and Long-term Alliance Success: The Role of the Alliance Function." Strategic Management Journal, 23: 747-767.

Kale, P., \& Puranam, P. (2004). "Choosing Equity Stakes in Technology-sourcing Relationships: An Integrative Framework." California Management Review, 46: 77-99.

Kortum, S. \& J. Lerner (1999). "What is Behind the Recent Surge in Patenting?" Research Policy, 28: 122.

Koza, M.P., \& Lewin, A.Y. (1998). "The Co-evolution of Strategic Alliances." Organization Science, 9: 255-264.

Leiblein, M.J. \& Miller, D. J. (2003). "An Empirical Examination of Transaction- and Firm-level Influences on the Vertical Boundaries of the Firm." Strategic Management Journal, 24: 839-859.

Lerner, J. (1994). "The Importance of Patent Scope: An Empirical Analysis," RAND Journal of Economics, 25: 319-333.

Levin, R.A., Klevorick A., Nelson, R., \& Winter, S. (1987). "Appropriating the Returns from Industrial R\&D," Brookings Papers on Economic Activity - Microeconomics.

Levinthal, D.A., \& March, J.G. (1993). "The Myopia of Learning." Strategic Management Journal, 14: 95-112. 
Levitt, B., \& March, J.G. (1988). “Organizational Learning.” in W.R. Scott \& J.F. Short (eds.), Annual Review of Sociology, vol. 14: 319-340. Palo Alto, CA: Annual Reviews.

Mayer, K.J. \& Argyres, N.S. (2004). "Learning to Contract: Evidence from the Personal Computer Industry," Organization Science, 15: 394-410.

Mayer, K.J. \& Nickerson, J.A. (2005). "Antecedents and Performance Implications of Contracting for Knowledge Workers: Evidence from Information Technology Services," Organization Science, 16: 225242.

Mayer, K.J. \& Salomon, R.M. (2006). "Capabilities, Contractual Hazards, and Governance: Integrating Resource-based and Transaction Cost Perspectives." USC and NYU working paper.

Monteverde, K., \& Teece, D.J. (1982). "Supplier Switching Costs and Vertical Integration in the Automobile Industry.” Bell Journal of Economics, 13: 206-213.

Oxley, J.E. (1997). “Appropriability Hazards and Governance in Strategic Alliances: A Transaction Cost Approach.” Journal of Law, Economics, \& Organization, 13: 387-409.

Oxley, J.E., \& Sampson, R.C. (2004). “The Scope and Governance of International R\&D Alliances.” Strategic Management Journal, 25: 723-749.

Pisano, G.P. (1989). "Using Equity Participation to Support Exchange: Evidence from the Biotechnology Industry." Journal of Law, Economics, \& Organization, 5: 109-126.

Poppo. L., \& Zenger, T. (2002). "Do Formal Contracts and Relational Governance Function as Substitutes or Complements?" Strategic Management Journal, 23: 707-725.

Ritter, J.R. (1984). “The 'Hot Issue' Market of 1980,” Journal of Business, 57: 215-241.

Rothaermel, F.T. (2001). "Incumbent's Advantage Through Exploiting Complementary Assets Via Interfirm Cooperation.” Strategic Management Journal, 22: 687-699.

Sampson, R.C. (2004a). "Organizational Choice in R\&D Alliances: Knowledge-based and Transaction Cost Perspectives." Managerial and Decision Economics, 25: 421-436.

Sampson, R.C. (2004b). "The Cost of Misaligned Governance in R\&D Alliances." Journal of Law, Economics and Organization, 20: 484-526.

Sampson, R.C. (2005). "Experience Effects and Collaborative Returns in R\&D Alliances." Strategic Management Journal, 26: 1009-1031.

Santoro, M.D., \& McGill, J.P. (2005). "The Effect of Uncertainty and Asset Co-specialization on Governance in Biotechnology Alliances.” Strategic Management Journal, 26: 1261-1269.

Shan, W., Walker, G., \& Kogut, B. (1994). "Interfirm Cooperation and Startup Innovation in the Biotechnology Industry." Strategic Management Journal, 15: 387-394.

Sorensen, M. (forthcoming). "How Smart Is Smart Money? An Empirical Two-Sided Matching Model of Venture Capital." Journal of Finance. 
Stein, J.C. (1989). "Efficient Capital Markets, Inefficient Firms: A Model of Myopic Corporate Behavior," Quarterly Journal of Economics, 104: 655-669.

Teece, D. (1986). "Profiting from Technological Innovation: Implications for Integration, Collaboration, Licensing, and Public Policy," Research Policy, 15: 285-305.

Villalonga, B., \& McGahan, A.M. (2005). "The Choice Among Acquisitions, Alliances, and Divestitures." Strategic Management Journal, 25: 1183-1208.

Walsh, J.P. \& Ungson, G.R. (1991). “Organizational Memory,” Academy of Management Review, 16: 57-91.

Wernerfelt, B. (1984). “A Resource-based View of the Firm.” Strategic Management Journal, 5: 171180.

Williamson, O.E. (1975). Market and Hierarchies: Analysis and Antitrust Implications. New York, NY: The Free Press.

Zollo, M., Reuer, J.J., \& Singh. H. (2002). "Interorganizational Routines and Performance in Strategic Alliances." Organization Science, 13: 701-713. 
Table 1

Summary Statistics and Variable Definitions*

\begin{tabular}{|c|c|c|c|}
\hline VARIABLE & DEFINITION & MEAN & STD. DEV. \\
\hline \multicolumn{4}{|l|}{ Dependent variables } \\
\hline Equity-use intensity & $\begin{array}{l}\text { Percentage of all R\&D deals for the firm in the year } \\
\text { where there is an equity component }\end{array}$ & 0.17 & 0.34 \\
\hline License-only intensity & $\begin{array}{l}\text { Percentage of all R\&D deals for the firm in that year } \\
\text { where licensing is the only deal component }\end{array}$ & 0.21 & 0.35 \\
\hline Firm valuation & $\begin{array}{l}\text { Most recent VC valuation for private years; market } \\
\text { capitalization for public years (in } \$ M \text { ) }\end{array}$ & 373.99 & 1219.76 \\
\hline \multicolumn{4}{|l|}{ Independent variables } \\
\hline \multicolumn{4}{|c|}{ Governance capability measures } \\
\hline 1) Equity-use deal stock & $\begin{array}{l}\text { Total number of equity R\&D deals by the focal firm to } \\
\text { that date }\end{array}$ & 0.88 & 1.42 \\
\hline 2) License-only deal stock & $\begin{array}{l}\text { Total number of pure licensing R\&D deals by the focal } \\
\text { firm to that date }\end{array}$ & 1.25 & 2.75 \\
\hline 3) Equity-use deviation & $\begin{array}{l}\text { Equity-use activity deviation in year } t \text { from the average } \\
\text { equity-use activity normalized by total alliances }\end{array}$ & -0.02 & 0.29 \\
\hline 4) License-only deviation & $\begin{array}{l}\text { Licensing-only activity deviation in year } t \text { from the } \\
\text { average licensing-only activity normalized by total } \\
\text { alliances }\end{array}$ & 0.07 & 0.49 \\
\hline \multicolumn{4}{|l|}{ Transaction cost measures } \\
\hline 5) Therapeutic scope & $\begin{array}{l}\text { Number of distinct therapeutic segments the firm is } \\
\text { involved in during that year }\end{array}$ & 2.27 & 1.83 \\
\hline 6) Patent stock & $\begin{array}{l}\text { Total number of patent applications by a firm as of } \\
2004\end{array}$ & 9.73 & 25.17 \\
\hline $\begin{array}{l}\text { 7) Prior partner } \\
\text { experience }\end{array}$ & $\begin{array}{l}\text { Number of alliance events prior to that firm-year } \\
\text { involving the firm's current year partners }\end{array}$ & 0.17 & 0.37 \\
\hline 8) Average deal scope & $\begin{array}{l}\text { \# of business categories spanned by the average deal in } \\
\text { a firm-year excluding equity-use and licensing-only }\end{array}$ & 0.99 & 1.02 \\
\hline \multicolumn{4}{|l|}{ Firm-level controls } \\
\hline 9) Firm age & Age of firm in years (since founding) & 8.24 & 6.32 \\
\hline 10) Number of employees & Number of employees in a firm-year & 552.42 & 1806.63 \\
\hline 11) Public firm dummy & Dummy $=1$ if the focal firm is publicly traded & 0.61 & 0.49 \\
\hline $\begin{array}{l}\text { 12) Discovery stage } \\
\text { projects }\end{array}$ & $\begin{array}{l}\text { Number of alliances during a firm-year that are at the } \\
\text { discovery stage }\end{array}$ & 0.30 & 0.98 \\
\hline $\begin{array}{l}\text { 13) New therapeutic area } \\
\text { dummy }(t-2)\end{array}$ & $\begin{array}{l}\text { Dummy }=1 \text { if the firm entered a new therapeutic area } \\
\text { via an alliance } 2 \text {-years prior to time } t\end{array}$ & 0.17 & 0.37 \\
\hline 14) VC amount invested & $\begin{array}{l}\text { Total amount of VC equity invested in the firm by all } \\
\text { VC firms up to a given year }\end{array}$ & 11046.40 & 24847.06 \\
\hline 15) Lerner index level & $\begin{array}{l}\text { Average level of the Lerner Biotechnology Index for } \\
\text { the firm-year }\end{array}$ & 4.81 & 2.51 \\
\hline
\end{tabular}

* The natural logarithm of a variable, $\mathrm{X}$, will be denoted L X. 
Table 2

Pair-wise Correlation Matrix of Independent Variables

\begin{tabular}{|c|c|c|c|c|c|c|c|c|c|c|c|c|c|c|c|}
\hline & (1) & (2) & (3) & (4) & (5) & (6) & (7) & (8) & (9) & (10) & (11) & (12) & (13) & (14) & (15) \\
\hline (1) & 1 & & & & & & & & & & & & & & \\
\hline (2) & 0.12 & 1 & & & & & & & & & & & & & \\
\hline (3) & -0.03 & 0.05 & 1 & & & & & & & & & & & & \\
\hline (4) & 0.10 & 0.14 & -0.04 & 1 & & & & & & & & & & & \\
\hline (5) & 0.09 & 0.28 & 0.10 & 0.08 & 1 & & & & & & & & & & \\
\hline (6) & 0.23 & 0.19 & 0.10 & -0.10 & 0.27 & 1 & & & & & & & & & \\
\hline (7) & 0.11 & 0.34 & 0.05 & -0.06 & 0.23 & 0.22 & 1 & & & & & & & & \\
\hline (8) & 0.14 & -0.23 & -0.25 & 0.21 & -0.08 & -0.06 & -0.23 & 1 & & & & & & & \\
\hline (9) & 0.27 & 0.30 & 0.04 & -0.06 & 0.04 & 0.55 & 0.12 & -0.16 & 1 & & & & & & \\
\hline (10) & -0.02 & -0.01 & -0.07 & -0.12 & -0.14 & 0.10 & -0.04 & -0.17 & 0.11 & 1 & & & & & \\
\hline (11) & 0.06 & 0.03 & -0.05 & 0.05 & 0.03 & 0.06 & 0.05 & -0.19 & 0.12 & 0.03 & 1 & & & & \\
\hline (12) & -0.07 & 0.39 & 0.05 & -0.03 & 0.30 & -0.04 & 0.36 & -0.21 & -0.11 & -0.01 & -0.03 & 1 & & & \\
\hline (13) & -0.01 & -0.10 & -0.11 & 0.06 & -0.03 & -0.15 & -0.03 & 0.13 & -0.24 & 0.01 & -0.09 & 0.01 & 1 & & \\
\hline (14) & 0.02 & 0.00 & 0.06 & -0.08 & 0.18 & 0.42 & 0.03 & 0.07 & -0.01 & -0.10 & 0.02 & 0.02 & 0.01 & 1 & \\
\hline (15) & 0.11 & 0.17 & 0.12 & -0.13 & 0.29 & 0.20 & 0.05 & -0.17 & 0.19 & -0.16 & 0.02 & 0.20 & -0.17 & 0.37 & 1 \\
\hline
\end{tabular}

Note: independent variable numbering corresponds to Table 1 numbering. 
Table 3

Equity-use Intensity Fixed-Effects OLS Regressions

(Firm - year level analysis)

\begin{tabular}{|c|c|c|c|c|}
\hline \multirow[b]{2}{*}{$\begin{array}{l}\text { Independent } \\
\text { Variables }\end{array}$} & \multicolumn{4}{|c|}{ Dependent Variable = Equity-use intensity } \\
\hline & (3-1) & (3-2) & 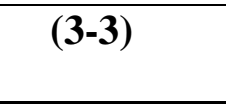 & (3-4) \\
\hline L equity-use deal stock & $\begin{array}{l}0.182^{* * * *} \\
(0.030)\end{array}$ & $\begin{array}{l}0.359 * * * \\
(0.067)\end{array}$ & & $\begin{array}{l}0.380^{* * * *} \\
(0.086)\end{array}$ \\
\hline L license-only deal stock & $\begin{array}{l}-0.198^{* * * *} \\
(0.025)\end{array}$ & $\begin{array}{l}-0.084 \\
(0.056)\end{array}$ & & $\begin{array}{c}0.003 \\
(0.081) \\
\end{array}$ \\
\hline L therapeutic scope & & & $\begin{array}{l}-0.053 \\
(0.066)\end{array}$ & $\begin{array}{l}-0.014 \\
(0.038)\end{array}$ \\
\hline L patent stock & & & $\begin{array}{l}-0.108 \text { *** } \\
(0.040)\end{array}$ & $\begin{array}{l}-0.129 * * * * \\
(0.041)\end{array}$ \\
\hline $\begin{array}{l}\text { prior partner } \\
\text { experience }\end{array}$ & & & $\begin{array}{c}0.040 \\
(0.039) \\
\end{array}$ & $\begin{array}{c}0.013 \\
(0.038) \\
\end{array}$ \\
\hline L average deal scope & & & $\begin{array}{l}0.185^{* * * *} \\
(0.045)\end{array}$ & $\begin{array}{l}0.176^{* * * *} \\
(0.042)\end{array}$ \\
\hline $\begin{array}{l}\text { New therapeutic area } \\
\text { dummy }(t-2)\end{array}$ & & $\begin{array}{l}0.066 * * \\
(0.033)\end{array}$ & $\begin{array}{l}0.104 * * \\
(0.047)\end{array}$ & $\begin{array}{c}0.066 \\
(0.046)\end{array}$ \\
\hline L VC amount invested & & $\begin{array}{c}0.009 \\
(0.013)\end{array}$ & $\begin{array}{c}0.018 \\
(0.015)\end{array}$ & $\begin{array}{c}0.015 \\
(0.016)\end{array}$ \\
\hline L firm age & & $\begin{array}{l}-0.131^{*} \\
(0.068)\end{array}$ & $\begin{array}{l}0.241^{* *} \\
(0.118)\end{array}$ & $\begin{array}{c}0.111 \\
(0.118)\end{array}$ \\
\hline L number of employees & & $\begin{array}{l}-0.033 \\
(0.026)\end{array}$ & $\begin{array}{c}0.042 \\
(0.035)\end{array}$ & $\begin{array}{l}-0.004 \\
(0.037)\end{array}$ \\
\hline Public firm dummy & & $\begin{array}{c}0.034 \\
(0.051)\end{array}$ & $\begin{array}{c}0.166 \\
(0.234) \\
\end{array}$ & $\begin{array}{l}-0.057 \\
(0.227)\end{array}$ \\
\hline $\begin{array}{l}\text { discovery stage } \\
\text { projects }\end{array}$ & & $\begin{array}{l}-0.032 \\
(0.028)\end{array}$ & $\begin{array}{l}-0.020 \\
(0.037)\end{array}$ & $\begin{array}{l}-0.030 \\
(0.035)\end{array}$ \\
\hline Lerner index level & & $\begin{array}{l}-0.007 \\
(0.006)\end{array}$ & $\begin{array}{c}0.002 \\
(0.008) \\
\end{array}$ & $\begin{array}{l}-0.003 \\
(0.008) \\
\end{array}$ \\
\hline Firm fixed effects & Yes & Yes & Yes & Yes \\
\hline Constant & $\begin{array}{l}0.174 * * * \\
(0.025)\end{array}$ & $\begin{array}{l}0.289^{* *} \\
(0.122)\end{array}$ & $\begin{array}{l}-0.781 * * * \\
(0.310)\end{array}$ & $\begin{array}{l}-0.287 \\
(0.317)\end{array}$ \\
\hline R-squared & 0.30 & 0.40 & 0.44 & 0.51 \\
\hline Num. Observations & 590 & 293 & 203 & 203 \\
\hline
\end{tabular}

$*, * *$ or $* * *$ indicate statistical significance at the $10 \%, 5 \%$ or $1 \%$ level, respectively. 
Table 4

\section{License-only Intensity Firm Fixed-Effects OLS Regressions (Firm - year level analysis)}

\begin{tabular}{|c|c|c|c|c|}
\hline \multirow[b]{2}{*}{$\begin{array}{l}\text { Independent } \\
\text { Variables }\end{array}$} & \multicolumn{4}{|c|}{ Dependent Variable $=$ License-only intensity } \\
\hline & (4-1) & (4-2) & (4-3) & (4-4) \\
\hline L equity-use deal stock & $\begin{array}{l}-0.204^{* * * *} \\
(0.032)\end{array}$ & $\begin{array}{l}-0.075 \\
(0.078)\end{array}$ & & $\begin{array}{l}-0.124 \\
(0.099)\end{array}$ \\
\hline L license-only deal stock & $\begin{array}{l}0.185^{* * *} \\
(0.027)\end{array}$ & $\begin{array}{l}0.377 * * * \\
(0.065)\end{array}$ & & $\begin{array}{l}0.426^{* * * *} \\
(0.092)\end{array}$ \\
\hline L therapeutic scope & & & $\begin{array}{c}0.031 \\
(0.076)\end{array}$ & $\begin{array}{c}0.119 \\
(0.073)\end{array}$ \\
\hline L patent stock & & & $\begin{array}{c}0.015 \\
(0.047)\end{array}$ & $\begin{array}{l}-0.063 \\
(0.047)\end{array}$ \\
\hline $\begin{array}{l}\text { prior partner } \\
\text { experience }\end{array}$ & & & $\begin{array}{l}0.114 * * * \\
(0.045)\end{array}$ & $\begin{array}{l}0.105^{* *} \\
(0.043)\end{array}$ \\
\hline $\begin{array}{l}\text { New therapeutic area } \\
\text { dummy }(t-2)\end{array}$ & & $\begin{array}{l}-0.017 \\
(0.038)\end{array}$ & $\begin{array}{l}-0.036 \\
(0.055)\end{array}$ & $\begin{array}{l}-0.002 \\
(0.052)\end{array}$ \\
\hline LVC amount invested & & $\begin{array}{l}-0.020 \\
(0.015)\end{array}$ & $\begin{array}{c}0.019 \\
(0.018)\end{array}$ & $\begin{array}{l}-0.013 \\
(0.018)\end{array}$ \\
\hline L firm age & & $\begin{array}{l}-0.257^{* * * *} \\
(0.079)\end{array}$ & $\begin{array}{l}-0.079 \\
(0.137)\end{array}$ & $\begin{array}{l}-0.140 \\
(0.136)\end{array}$ \\
\hline L number of employees & & $\begin{array}{c}0.046 \\
(0.030)\end{array}$ & $\begin{array}{l}-0.055^{*} \\
(0.041)\end{array}$ & $\begin{array}{c}0.039 \\
(0.043)\end{array}$ \\
\hline Public firm dummy & & $\begin{array}{c}0.014 \\
(0.059)\end{array}$ & $\begin{array}{l}-0.502^{*} \\
(0.271)\end{array}$ & $\begin{array}{l}-0.336 \\
(0.259)\end{array}$ \\
\hline $\begin{array}{l}\text { discovery stage } \\
\text { projects }\end{array}$ & & $\begin{array}{c}0.000 \\
(0.033)\end{array}$ & $\begin{array}{l}-0.036 \\
(0.043)\end{array}$ & $\begin{array}{l}-0.025 \\
(0.040)\end{array}$ \\
\hline Lerner index level & & $\begin{array}{c}0.012 \\
(0.007) \\
\end{array}$ & $\begin{array}{c}0.019 * * \\
(0.009)\end{array}$ & $\begin{array}{c}0.013 \\
(0.009) \\
\end{array}$ \\
\hline Firm fixed effects & Yes & Yes & Yes & Yes \\
\hline Constant & $\begin{array}{l}0.137 * * * \\
(0.027)\end{array}$ & $\begin{array}{c}0.171 \\
(0.142)\end{array}$ & $\begin{array}{l}0.791 * * \\
(0.361)\end{array}$ & $\begin{array}{l}0.215 \\
(0.372)\end{array}$ \\
\hline R-squared & 0.26 & 0.34 & 0.35 & 0.45 \\
\hline Num. Observations & 590 & 293 & 203 & 203 \\
\hline
\end{tabular}

\footnotetext{
$*, * *$ or $* * *$ indicate statistical significance at the $10 \%, 5 \%$ or $1 \%$ level, respectively.
} 
Table 5

Cooperative Mode Multinomial Logits (Transaction level analysis)

\begin{tabular}{|c|c|c|c|c|c|c|}
\hline & \multicolumn{6}{|c|}{ Dependent variable = EQUITY-USE or LICENSE-ONLY [default = other], robust std errors reported (clustered by firm) } \\
\hline & \multicolumn{2}{|c|}{$(5-1)$} & \multicolumn{2}{|c|}{$(5-2)$} & \multicolumn{2}{|c|}{$(5-3)$} \\
\hline & Equity-use & License-only & Equity-use & License-only & Equity-use & License-only \\
\hline L equity-use deal stock & $\begin{array}{l}2.436 * * * \\
(0.457)\end{array}$ & $\begin{array}{l}-0.231 \\
(0.154)\end{array}$ & & & $\begin{array}{l}2.718 * * * \\
(0.539)\end{array}$ & $\begin{array}{l}-0.232 \\
(0.180)\end{array}$ \\
\hline L license-only deal stock & $\begin{array}{l}-0.660 * * * \\
(0.195)\end{array}$ & $\begin{array}{l}0.759 * * * \\
(0.092)\end{array}$ & & & $\begin{array}{l}-0.785 * * * \\
(0.316)\end{array}$ & $\begin{array}{l}0.761 * * * \\
(0.114)\end{array}$ \\
\hline L therapeutic scope & & & $\begin{array}{l}-0.147 \\
(0.672)\end{array}$ & $\begin{array}{l}0.435 * * \\
(0.206)\end{array}$ & $\begin{array}{l}-0.104 \\
(0.413)\end{array}$ & $\begin{array}{l}-0.016 \\
(0.229)\end{array}$ \\
\hline L patent stock & & & $\begin{array}{l}0.427 * \\
(0.223)\end{array}$ & $\begin{array}{c}0.162 \\
(0.135)\end{array}$ & $\begin{array}{c}0.151 \\
(0.218) \\
\end{array}$ & $\begin{array}{c}0.151 \\
(0.147)\end{array}$ \\
\hline L prior partner experience & & & $\begin{array}{l}-0.403 \\
(0.278)\end{array}$ & $\begin{array}{c}0.239 \\
(0.185)\end{array}$ & $\begin{array}{l}-0.167 \\
(0.385)\end{array}$ & $\begin{array}{c}0.072 \\
(0.148)\end{array}$ \\
\hline $\begin{array}{l}\text { New therapeutic area dummy } \\
(t-2)\end{array}$ & $\begin{array}{l}-0.274 \\
(0.273)\end{array}$ & $\begin{array}{l}-0.011 \\
(0.181)\end{array}$ & $\begin{array}{l}-0.376 \\
(0.308)\end{array}$ & $\begin{array}{l}-0.096 \\
(0.223)\end{array}$ & $\begin{array}{l}-0.446 \\
(0.301)\end{array}$ & $\begin{array}{c}0.055 \\
(0.221)\end{array}$ \\
\hline L VC amount invested & $\begin{array}{c}0.057 \\
(0.039)\end{array}$ & $\begin{array}{l}0.054 * * \\
(0.024)\end{array}$ & $\begin{array}{c}0.043 \\
(0.061)\end{array}$ & $\begin{array}{c}0.036 \\
(0.029)\end{array}$ & $\begin{array}{l}-0.030 \\
(0.048)\end{array}$ & $\begin{array}{c}0.047 \\
(0.032)\end{array}$ \\
\hline L firm age & $\begin{array}{l}-0.481 * \\
(0.262)\end{array}$ & $\begin{array}{c}0.260 \\
(0.201)\end{array}$ & $\begin{array}{l}-0.683 \\
(0.479)\end{array}$ & $\begin{array}{c}0.208 \\
(0.352)\end{array}$ & $\begin{array}{l}-1.077 * * \\
(0.514)\end{array}$ & $\begin{array}{l}-0.154 \\
(0.313)\end{array}$ \\
\hline L number of employees & $\begin{array}{l}-0.354 \\
(0.244)\end{array}$ & $\begin{array}{l}-0.179 * * \\
(0.087)\end{array}$ & $\begin{array}{l}-0.117 \\
(0.157)\end{array}$ & $\begin{array}{l}-0.209 \\
(0.149)\end{array}$ & $\begin{array}{c}0.004 \\
(0.293)\end{array}$ & $\begin{array}{l}-0.214 \\
(0.144)\end{array}$ \\
\hline Lerner index level & $\begin{array}{l}-0.199 * * * \\
(0.076)\end{array}$ & $\begin{array}{l}-0.013 \\
(0.045)\end{array}$ & $\begin{array}{l}-0.231 * * \\
(0.105)\end{array}$ & $\begin{array}{l}-0.011 \\
(0.058)\end{array}$ & $\begin{array}{l}-0.280 * * * \\
(0.087)\end{array}$ & $\begin{array}{c}0.030 \\
(0.053)\end{array}$ \\
\hline Deal stage dummies & Yes (4) & Yes (4) & Yes (4) & Yes (4) & Yes (4) & Yes (4) \\
\hline Therapeutic area dummies & Yes (5) & Yes (5) & Yes (5) & Yes (5) & Yes (5) & Yes (5) \\
\hline Constant & $\begin{array}{l}-0.717 \\
(1.043) \\
\end{array}$ & $\begin{array}{l}-2.395 * * * \\
(0.556)\end{array}$ & $\begin{array}{c}0.352 \\
(1.222) \\
\end{array}$ & $\begin{array}{l}-2.261 * * * \\
(0.841)\end{array}$ & $\begin{array}{l}-0.404 \\
(1.320) \\
\end{array}$ & $\begin{array}{l}-1.670 * * \\
(0.857)\end{array}$ \\
\hline Log likelihood / Num Obs & \multicolumn{2}{|c|}{$\mathrm{LL}=-620.03 / \mathrm{N}=1198$} & \multicolumn{2}{|c|}{$\mathrm{LL}=-498.59 / \mathrm{N}=866$} & \multicolumn{2}{|c|}{$\mathrm{LL}=-457.74 / \mathrm{N}=866$} \\
\hline
\end{tabular}

\footnotetext{
$*, * *$ or $* * *$ indicates statistical significance at the $10 \%, 5 \%$, and $1 \%$ levels, respectively
} 


\section{Table 6}

\section{Firm Valuation Firm Fixed-Effects OLS Regressions (Firm - year analysis)}

\begin{tabular}{|c|c|c|c|}
\hline \multirow[b]{2}{*}{ Independent Var. } & \multicolumn{3}{|c|}{ Dependent Variable $=$ L Firm Valuation } \\
\hline & $(6-1)$ & $(6-2)$ & $(6-3)$ \\
\hline L equity-use deal stock & $\begin{array}{l}1.783 * * * \\
(0.180)\end{array}$ & $\begin{array}{l}0.676 * * \\
(0.347)\end{array}$ & $\begin{array}{c}0.529 * \\
(0.306)\end{array}$ \\
\hline L license-only deal stock & $\begin{array}{l}0.424 * * * \\
(0.160)\end{array}$ & $\begin{array}{l}0.922 * * * \\
(0.318)\end{array}$ & $\begin{array}{l}0.747 * * * \\
(0.279)\end{array}$ \\
\hline L license-only deviation & $\begin{array}{l}-0.465 * * * \\
(0.148)\end{array}$ & $\begin{array}{l}-0.373^{*} \\
(0.199)\end{array}$ & $\begin{array}{l}-0.749 * * \\
(0.317)\end{array}$ \\
\hline L license-only deviation squared & $\begin{array}{l}-0.215^{* * *} \\
(0.075)\end{array}$ & $\begin{array}{l}-0.355^{* * * *} \\
(0.113)\end{array}$ & $\begin{array}{l}-0.299 * * * \\
(0.098)\end{array}$ \\
\hline Lequity use deviation & $\begin{array}{c}0.258 \\
(0.218)\end{array}$ & $\begin{array}{l}-0.365 \\
(0.309)\end{array}$ & $\begin{array}{l}-0.647 \\
(0.511)\end{array}$ \\
\hline L equity use deviation squared & $\begin{array}{c}0.188 \\
(0.136)\end{array}$ & $\begin{array}{l}-0.131 \\
(0.218)\end{array}$ & $\begin{array}{l}-0.097 \\
(0.207)\end{array}$ \\
\hline L therapeutic scope & & $\begin{array}{c}0.267 \\
(0.247) \\
\end{array}$ & $\begin{array}{l}-0.083 \\
(0.222)\end{array}$ \\
\hline$\overline{L \text { patent scope }}$ & & $\begin{array}{l}-0.056 \\
(0.167)\end{array}$ & $\begin{array}{l}-0.028 \\
(0.148)\end{array}$ \\
\hline L prior partner experience & & $\begin{array}{l}-0.173 \\
(0.143)\end{array}$ & $\begin{array}{l}-0.003 \\
(0.128)\end{array}$ \\
\hline L average deal scope & & $\begin{array}{l}-0.242 \\
(0.211)\end{array}$ & $\begin{array}{l}-0.138 \\
(0.186)\end{array}$ \\
\hline New therapeutic area dummy $(t-2)$ & & $\begin{array}{c}0.116 \\
(0.175)\end{array}$ & $\begin{array}{c}0.190 \\
(0.153)\end{array}$ \\
\hline L VC amount invested & & $\begin{array}{l}-0.132 * * \\
(0.060)\end{array}$ & $\begin{array}{l}-0.069 \\
(0.053)\end{array}$ \\
\hline L firm age & & $\begin{array}{l}-0.221 \\
(0.460)\end{array}$ & $\begin{array}{l}-0.649 \\
(0.414)\end{array}$ \\
\hline L number of employees & & $\begin{array}{l}0.592 * * * \\
(0.189)\end{array}$ & $\begin{array}{l}0.484 * * * \\
(0.169)\end{array}$ \\
\hline L discovery stage projects & & $\begin{array}{l}0.362 * * * \\
(0.136)\end{array}$ & $\begin{array}{l}0.261 * * \\
(0.119)\end{array}$ \\
\hline Lerner index level & & & $\begin{array}{l}0.176^{* * *} \\
(0.026)\end{array}$ \\
\hline $\begin{array}{l}\text { Lerner index level } * \\
\text { license-only deviation }\end{array}$ & & & $\begin{array}{l}0.076^{* * *} \\
(0.038)\end{array}$ \\
\hline $\begin{array}{l}\text { Lerner index level * } \\
\text { equity use deviation }\end{array}$ & & & $\begin{array}{c}0.059 \\
(0.063)\end{array}$ \\
\hline Firm fixed effects & Yes & Yes & Yes \\
\hline Constant & $\begin{array}{l}3.021^{* * * *} \\
(0.184)\end{array}$ & $\begin{array}{l}2.123^{*} \\
(1.142)\end{array}$ & $\begin{array}{l}2.657 * * * \\
(0.994)\end{array}$ \\
\hline R-squared & 0.72 & 0.83 & 0.88 \\
\hline Num. Observations & 407 & 193 & 193 \\
\hline
\end{tabular}

$*, * *$ or *** indicate statistical significance at the $10 \%, 5 \%$ or $1 \%$ level, respectively. 


\section{Appendix Alliance and Firm-Level Segment Classifications}

Our 24 category therapeutic classification scheme is a derivative of the Anatomical Therapeutic Classification (ATC) system published by the World Health Organization's Collaborating Centre for Drug Statistics Methodology. The ATC system contains a five-level classification system for drugs with increasing specificity at lower levels. The top-level contains 14 categories; we retain 9 of these original categories, split 3 of the categories into either 2 or 3 sub-categories, and add 8 additional categories to accommodate firms and alliances with process or delivery-focused technologies, resulting in a 24 category classification scheme (Appendix). In classifying the alliances and firm-years, the original ATC therapeutic categories take precedence over the new categories.

Therapeutic Categories

Allergic (x)

Autoimmune (x)

Bioinformatics / Diagnostics / Drug Discovery (*)

MusculoSkeletal (o)

Cancer (x)

Cardiovascular (o)

Nervous System (o)

Drug Delivery $(*)$

Endocrinology \& Metabolic (x)

Gastrointestinal (x)

Genitourinary \& Gynecological (o)

Hematologic (o)

Infectious - Bacterial / Fungal (x)

Infectious - Viral (x)

Ophthalmology (o)

Orthopedics $(*)$

Respiratory (o)

Wound Healing (o)

Generics / Supplements (*)

Devices (*)

Veterinary (o)

RNAi (*)

Supplies / Reagents / Processing / Manufacturing (*)

Agricultural / Industrial Biotech (*)

(o) indicates an original ATC category or a derivative of an original ATC category

(x) indicates a category that has been split from an original ATC category

(*) indicates a new category 